Article

\title{
Impact of Cultivar, Harvest Date and Threshing Parameter Settings on Floret and Carthamidin Yield of Safflower
}

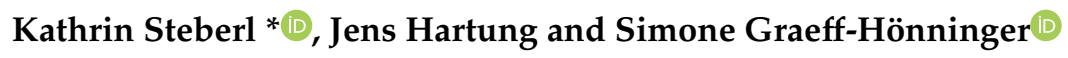 \\ Institute of Crop Science, University of Hohenheim, 70599 Stuttgart, Germany; \\ jens.hartung@uni-hohenheim.de (J.H.); simone.graeff@uni-hohenheim.de (S.G.-H.) \\ * Correspondence: Kathrin.Steberl@uni-hohenheim.de; Tel.: +49-711-459-24184
}

Received: 31 July 2020; Accepted: 25 August 2020; Published: 27 August 2020

check for updates

\begin{abstract}
The industrial need for safflower (Carthamus tinctorius L.) increased over the last decade due to its potential use as food colorant. Safflower is mainly cultivated in Asia for its use as floret. In Germany, an economically attractive cultivation for floret use would require a mechanization of harvest. In order to develop a mechanical harvesting system, field experiments were conducted at the experimental station Ihinger Hof of the University Hohenheim in 2017 and 2018. Safflower was harvested with a combine harvester to obtain the florets. Two safflower (i) cultivars were harvested with (ii) three threshing parameter settings on (iii) five harvest dates to evaluate threshed floret yield, dry matter and carthamidin content, and carthamidin yield. Results showed that the maximum threshed floret yield was achieved at the latest harvest date (784.78-1141.76 kg ha $\left.{ }^{-1}\right)$, while the highest carthamidin contents were observed depending on cultivar on the first two harvest dates $(0.53-3.14 \%)$. The decisive and resulting amount of carthamidin yield reached its maximum with the Chinese cultivar and the threshing parameter setting P3 between the fourth and fifth harvest date in $2018\left(19.05-19.36 \mathrm{~kg} \mathrm{ha}^{-1}\right)$. Highest dry matter contents were achieved at the last harvest date (62.67-77.77\%). Individual capitula weight and carthamidin content decreased with later harvest dates. Further investigations should clarify whether the individual capitula weight and carthamidin content correlate with each other or are independent of the date of harvest. This could be a decisive criterion for the selection of cultivars for harvesting florets with a combine harvester. Reduced costs of machine harvesting compared to hand harvesting will make the cultivation of safflower for the food coloring industry in Germany more attractive in the future.
\end{abstract}

Keywords: Carthamus tinctorius L.; safflower; threshing parameters; combine harvester; carthamidin content; carthamidin yield; mechanization; harvest

\section{Introduction}

Safflower (Carthamus tinctorius L.), a member of the Asteraceae family, has a deep-rooting system and a strong taproot [1-4]. Safflower is an annual, thistle-like plant with many spines on its bracts and leaves [1,2]. It branches out to tertiary branches [5]. Each one has a spherical flower head (capitulum) containing the white, yellow, orange or red petals (florets) $[1,2,5]$. It has many purposes, such as vegetable, animal feed, tea, cut flowers or as a medicinal plant $[1,2,6,7]$. It has been used by humans for over 2200 years $[1,5]$. The main benefit of safflower currently is its use as oil, which is regarded as a healthy alternative to sunflower oil due to its oil composition $[1,2,8,9]$. Traditionally, safflower florets were used for coloring food and textiles [1-3]. However, this traditional use receded into the background when cheaper, synthetic aniline colors were invented in $1856[2,10]$.

Different studies claim that these artificial food colorants negatively influence the behavior of children or may cause carcinogenic or allergic effects [11-14]. Therefore, and also due to the growing 
awareness of environmentally conscious, safe and healthy consumption, the attention to natural colorants has increased [13-17]. The 2013 EU directive "Guidance notes on the classification of food extracts with colouring properties" distinguishes between "dyes" and "coloring foods" [18,19]. "Dyes" are defined as additives requiring legal admission, which is not the case for "coloring foods" [18,20]. Due to the lower enrichment factor (variable to indicate accumulation of a substance in a living organism) of safflower compared to paprika and curcuma, it is considered as an appropriate yellowand orange-coloring substitute, which is increasingly used in, e.g., ice cream, candies, fruit syrups and juices $[7,18,21,22]$. Safflower has a number of advantages compared to other colorants, especially in the processing properties regarding light, temperature and $\mathrm{pH}$ value, and it is cheaper than saffron $[23,24]$.

On an international level, cultivation of safflower for the use of florets is currently limited and is still mainly practiced in Asia [1,2,25]. However, this will no longer be sufficient to meet the rising demand of the food coloring industry, especially in Europe and other Western countries [7,13,26-32]. With the expansion of the cultivation of safflower to other regions, an adaption of cultivar choice and cultivation methods to regional conditions is required. Several studies have shown that there are suitable cultivars of safflower for oil and seed production in Central Europe [33-37]. There have also been tests on the cultivation of safflower with the aim of gaining florets in southwest Germany, which showed that the cultivation is possible and that the floret yields, colorant contents and colorant yields (specified on carthamidin as yellow colorant) can compete with other international studies [28,38-43], but can vary between years, harvest dates and cultivars.

Safflower for floret production is mainly harvested by hand, which is very slow, labor- and time-intensive and expensive [44-46]. Due to the fact that there is no industrially produced harvesting machine for this type of use so far [44,45], the production efficiency is very low, which means that no economical, large-scale production of florets is possible currently [45]. Therefore, a suitable method for the mechanization of harvesting should be developed and tested.

Within the study, mechanized harvesting was tested. In order to reduce costs and offer an economically attractive way to produce florets in Germany, a combine harvester was chosen as a harvesting machine due to its availability to every farmer. The threshing efficiency is influenced by many variables: for example, threshing drum speed, crop moisture (or dry matter content) and concave setting $[47,48]$. Furthermore, the cleaning wind as well as the sieves have to be adapted to the crop [49].

The objectives of the present study were to (i) test different cultivars, (ii) assess harvest dates and (iii) investigate threshing parameter settings on threshed floret yield, dry matter content, carthamidin content and yield, when safflower is harvested with a combine harvester. Furthermore, it was investigated whether (iv) relationships between plant-specific characteristics (e.g., capitulum weight) and carthamidin content exist that impact the suitability of cultivars for mechanized harvesting.

\section{Materials and Methods}

\subsection{Description of the Experimental Site and Design}

Two field experiments were conducted at the experimental station Ihinger Hof of the University of Hohenheim in southwestern Germany $\left(48^{\circ} 44^{\prime} \mathrm{N}, 8^{\circ} 55^{\prime} \mathrm{E}, 478 \mathrm{~m}\right.$ a.s.l.) in 2017 and 2018. Annual temperature in $2018\left(10.2^{\circ} \mathrm{C}\right)$ was higher than in $2017\left(9.2^{\circ} \mathrm{C}\right)$ and the annual rainfall was lower in $2018(525.9 \mathrm{~mm})$ than in $2017(653.9 \mathrm{~mm})$. Detailed weather and soil conditions were described in Steberl et al. [38].

For the first experiment and for both experimental years 2017 and 2018, the field trial was arranged in a kind of split plot design with three replicates. The main plat factor was cultivar. The two levels of cultivar were the Chinese (C2) and German Cultivar (C1). In contrast to a common split-plot design with one main-plot per cultivar and replicate, the replicate was split into four main-plots. This increased the efficiency of cultivar mean estimates and comparison. The subplot factor is allocated to plot within main-plots according to an $\alpha$-design with two incomplete blocks (=main-plots). The plots had a size of $30 \mathrm{~m}^{2}(2 \times 15 \mathrm{~m})$ each containing four rows in the center with a row spacing of $0.33 \mathrm{~m}$. 
A sowing density of 40 plants $\mathrm{m}^{-2}$ was used to enable mechanical hoeing. This is essential due to a slow development of the plant up to the rosette stage [50], and the potential high weed pressure after emergence [51]. The row orientation was north-south in 2017 and east-west in 2018.

Information on previous crop, tillage, sowing and fertilization is similar to the experiment described in Steberl et al. [38]. In contrast to Steberl et al. [38] the sowing took place on 25 April 2017 and 20 April 2018. In 2017, manual weeding was done once 43 days after sowing (DAS). Because of high weed density in 2018, weeding was carried out three times $(6,33$ and 48 DAS). Afterwards, no additional weeding was required because plants reached the branching stage, where they are no longer susceptible to weeds $[50,52,53]$.

For the relationship between individual head weight and carthamidin content, data from the second field experiment was used, which is described in all details in Steberl et al. [38]. Thus, all remaining parts in the Materials and Methods section focus on the first experiment, except if stated differently.

\subsection{Treatments}

For both experiments, two different cultivars with three different threshing parameter settings were studied and harvested at different dates. The two safflower cultivars were a German (C1) and a Chinese cultivar (C2). These two cultivars are described in detail in Steberl et al. [38]. Due to the morphological differences, the growth habit and height, differences were assumed with regard to the threshed floret yield, the carthamidin content and, accordingly, the carthamidin yield.

For the first experiment, different threshing parameters for the setup of the combine harvester were selected based on a previous test in 2016. A range of combinations of top and bottom sieve, wind, threshing drum rpm (rounds per minute), concave setting and the use of a different number of rub bars or omission of them was selected. Threshing parameters in 2017 and 2018 were chosen from these combinations (P1-P3) (Table 1).

Table 1. List of threshing parameter settings (P1-P3) tested in the experimental years 2017 and 2018.

\begin{tabular}{cccc}
\hline Characteristics & P1 & P2 & P3 \\
\hline Top sieve (lamella sieve) & $15 \mathrm{~mm}$ opened & $9 \mathrm{~mm}$ opened & $15 \mathrm{~mm}$ opened \\
\hline Bottom sieve (round hole sieve) & $16 \mathrm{~mm}$ & $10 \mathrm{~mm}$ & $16 \mathrm{~mm}$ \\
\hline Wind & $400 \mathrm{~min}^{-1}$ & $400 \mathrm{~min}^{-1}$ & $500 \mathrm{~min}^{-1}$ \\
\hline Threshing drum & $1200 \mathrm{~min}^{-1}$ & $1200 \mathrm{~min}^{-1}$ & $700 \mathrm{~min}^{-1}$ \\
\hline Concave setting & Step 1 & Step 1 & Step 3 \\
\hline Rub bars & - & - & 3 \\
\hline
\end{tabular}

Harvest of the florets took place at different dates representing different dry matter contents and different stages of development. The first harvest was carried out when the majority of the plants of the cultivar had reached flowering (BBCH stage 65) [50]. Due to the fact that $\mathrm{C} 1$ flowers earlier than $\mathrm{C} 2$, the first harvest was planned when $\mathrm{C} 1$ started to flower. Thus, $\mathrm{C} 2$ was not yet flowering at that date (see BBCH stages in Table 2).

The second harvest took place when both cultivars were in full bloom. The third harvest was scheduled when flowering went towards the end for both cultivars. The fourth was planned when $\mathrm{C} 1$ was withered and C2 was still slightly flowering. The last harvest took place when both cultivars were already withered. At that date, plants were drier and therefore a higher threshability was expected [48,54-56]. Due to changing weather conditions, some of the planned harvests could not be realized. Table 2 gives an overview of all harvest dates in both years. 
Table 2. Sowing dates, and the number (BBCH stage $\mathrm{C} 1 / \mathrm{C} 2$ (Chinese/German cultivar)) and date of harvests (days after sowing (DAS)) in the experimental years 2017 and 2018.

\begin{tabular}{|c|c|c|c|}
\hline Year & Sowing Date & Harvest Time & Date of Harvest (DAS) \\
\hline \multirow{2}{*}{2017} & \multirow{2}{*}{25 April 2017} & $3(69 / 67)$ & $03.08(100)$ \\
\hline & & $4(71 / 69)$ & $14.08(111)$ \\
\hline \multirow{4}{*}{2018} & \multirow{4}{*}{20 April 2018} & $1(61 / 59)$ & $13.07(84)$ \\
\hline & & $2(67 / 65)$ & 24.07 (95) \\
\hline & & $4(71 / 69)$ & $09.08(111)$ \\
\hline & & $5(75 / 71)$ & $16.08(118)$ \\
\hline
\end{tabular}

\subsection{Data Collection}

\subsubsection{Harvesting and Post-Harvest Procedures}

At each harvest date, plots were harvested with a plot combine harvester "Zürn 150" (Zürn Harvesting $\mathrm{GmbH}$ and Co. KG, Schöntal-Westernhausen, Germany). Fresh and dry matter weight was recorded for these samples of harvested florets. The drying temperatures were $40{ }^{\circ} \mathrm{C}$, according to Mohammadi and Tavakoli [39], in order to prevent destruction of ingredients. Dry matter content was the result of the division of dry by fresh matter.

Despite the different threshing parameters, the threshed material still contained many coarse parts (leaves, branches, etc.) (Figure 1).

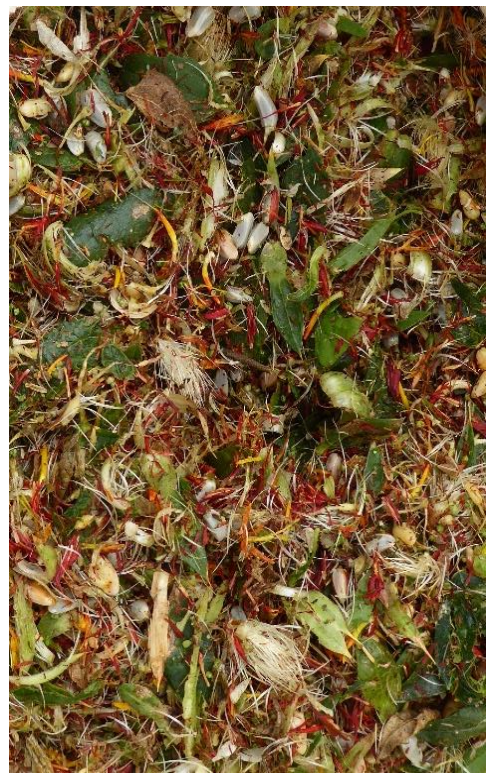

(a)

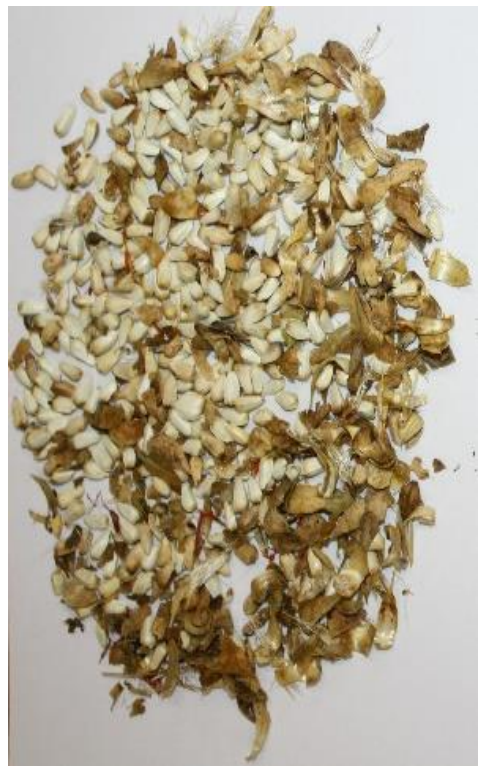

(b)

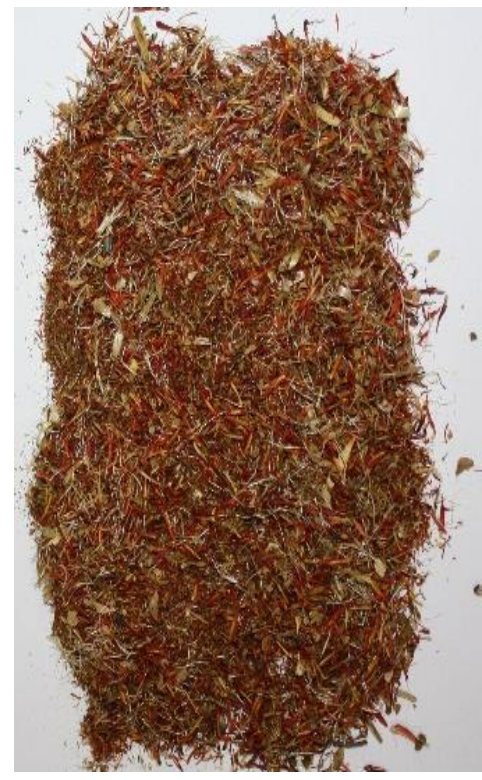

(c)

Figure 1. Photos of (a) threshed sample immediately after harvesting, (b) residue remaining in the sieve after sieving, (c) sample that was sieved and then used for further laboratory analysis.

In order to obtain a higher proportion of florets, a subsample of each plot was sieved with a $3 \mathrm{~mm}$ sieve as a post-harvest procedure, which is typical in flower production [57]. Data analysis was concentrated on sieved samples only. Therefore, they differed from the pure florets by still containing, e.g., small leaf parts, which is why they are called threshed florets in the following in order to avoid confusion with the pure florets.

In addition, number and weight (fresh and dry) of the capitula were recorded, as described in Steberl et al. [38]. 


\subsubsection{Laboratory Analyses for the Determination of Carthamidin Content}

Carthamidin content of the threshed florets was measured spectrophotometrically at the University of Hohenheim as described in $[39,58]$ with minor modification. Determination of the carthamidin content was described in detail in [38]. The carthamidin yield was calculated as the product of the threshed floret yield and carthamidin content [39]. The carthamidin contents in Section 3.5 were determined from pure florets, as described in Steberl et al. [38].

\subsection{Statistical Analysis}

Data were analyzed using a mixed model approach. In the syntax of Piepho [59], the model can be shown as:

$$
\mathrm{Y} / \mathrm{R}+\mathrm{Y} \times \mathrm{C} \times \mathrm{P} \times \mathrm{H}: \mathrm{B} \cdot \mathrm{R} \cdot \mathrm{Y}+\mathrm{B} \cdot \mathrm{R} \cdot \mathrm{H} \cdot \mathrm{Y}+\mathrm{R} \cdot \mathrm{C} \cdot \mathrm{P} \cdot \mathrm{Y}+\underline{\mathrm{R} \cdot \mathrm{C} \cdot \mathrm{P} \cdot \mathrm{Y} \cdot \mathrm{H}}
$$

where $\mathrm{Y}, \mathrm{R}, \mathrm{B}, \mathrm{C}, \mathrm{P}$ and $\mathrm{H}$ indicate the effects for year, replicate, incomplete block or main-plot within replicate, cultivar, threshing parameter settings and harvest dates. The nesting operator / expands, for example, $Y / R$ to $Y+Y \cdot R$. The crossing operator $\times$ expands, for example, $Y \times C$ to $Y+C+Y \cdot C$. Complete replicate effects within years are achieved through $Y \cdot R$ in the model. Due to the weather conditions, the years were very different. Since the interest was to find the best treatment for both years, the effect of the year was assumed to be fixed. In contrast, incomplete blocks within a replicate and year (B.R.Y), harvest date-specific incomplete block effects $(B \cdot R \cdot Y \cdot H)$ as well as plot effects (R.C.P.Y) were assumed as random. A colon is used to separate fixed effects and random effects (behind the colon) in the model. The residual error effects (R.C.P.Y.H) are underlined. A year-specific variance was fitted to these error effects. The assumptions of normal distribution residuals with homogenous variance were checked graphically via residual plots for all traits. In case of rejection of at least one assumption, a logarithmic or a square root transformation was performed to meet the criteria. In this case, the estimated means were back-transformed for presentation purpose only. Furthermore, standard errors were back-transformed by using the delta method. After finding significant effects via the F-test, significant differences were evaluated using the multiple Fisher's least significant difference test at a significance level of $\alpha=5 \%$. Using the \%mult macro in SAS [60], a letter display was generated to show the results of the multiple comparison. In case of multiple (two or three way) interactions, letter displays for all significant differences become complicated. Therefore, simple or marginal cultivar-by-threshing parameter settings-by-year-harvest date means of single higher-level interactions were presented in the result and discussion part to simplify the presentation of the results of the manuscript. Additionally, all relevant means were compared within the Appendix A.

The statistical analysis was performed using PROC MIXED of the statistical software SAS 9.4. (SAS Institute Inc., Cary, NC, USA).

\section{Results and Discussion}

\subsection{Threshed Floret Yield}

The analysis showed significant differences for year and for several two-way interactions of cultivar, threshing parameter settings and harvest date (Figure 2 and Table 3). 
(a)

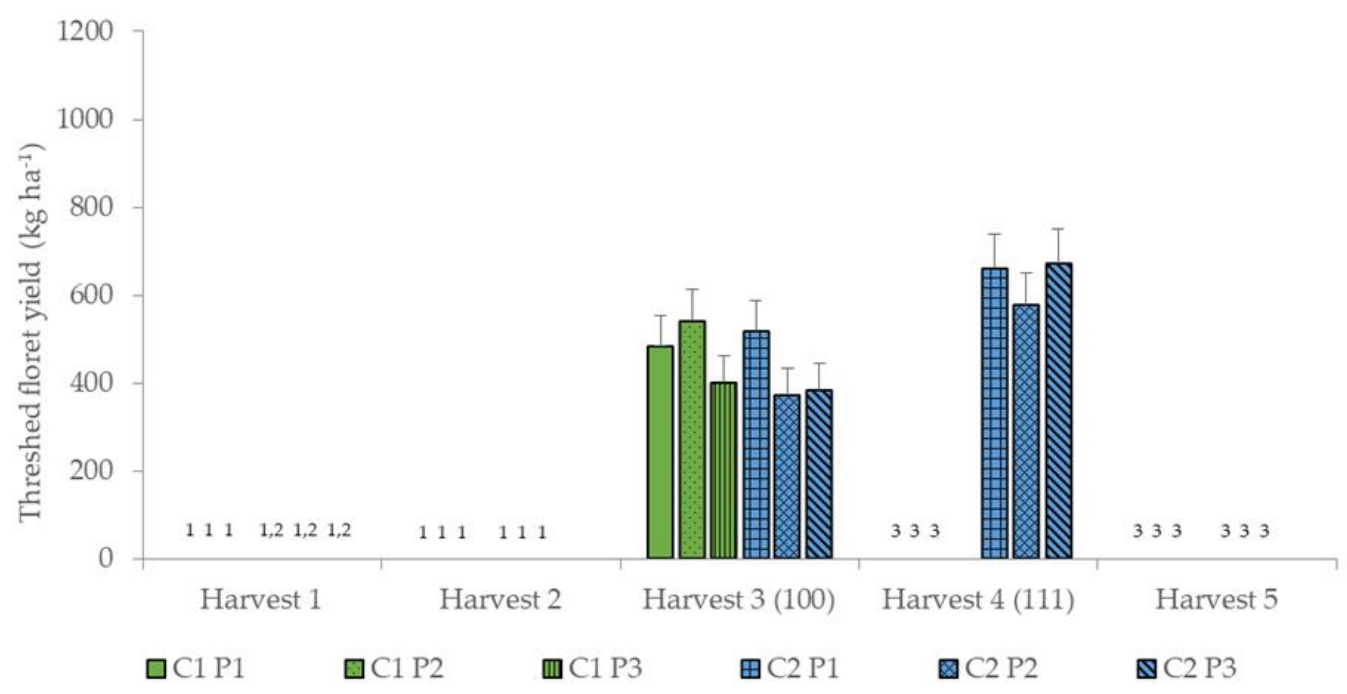

(b)

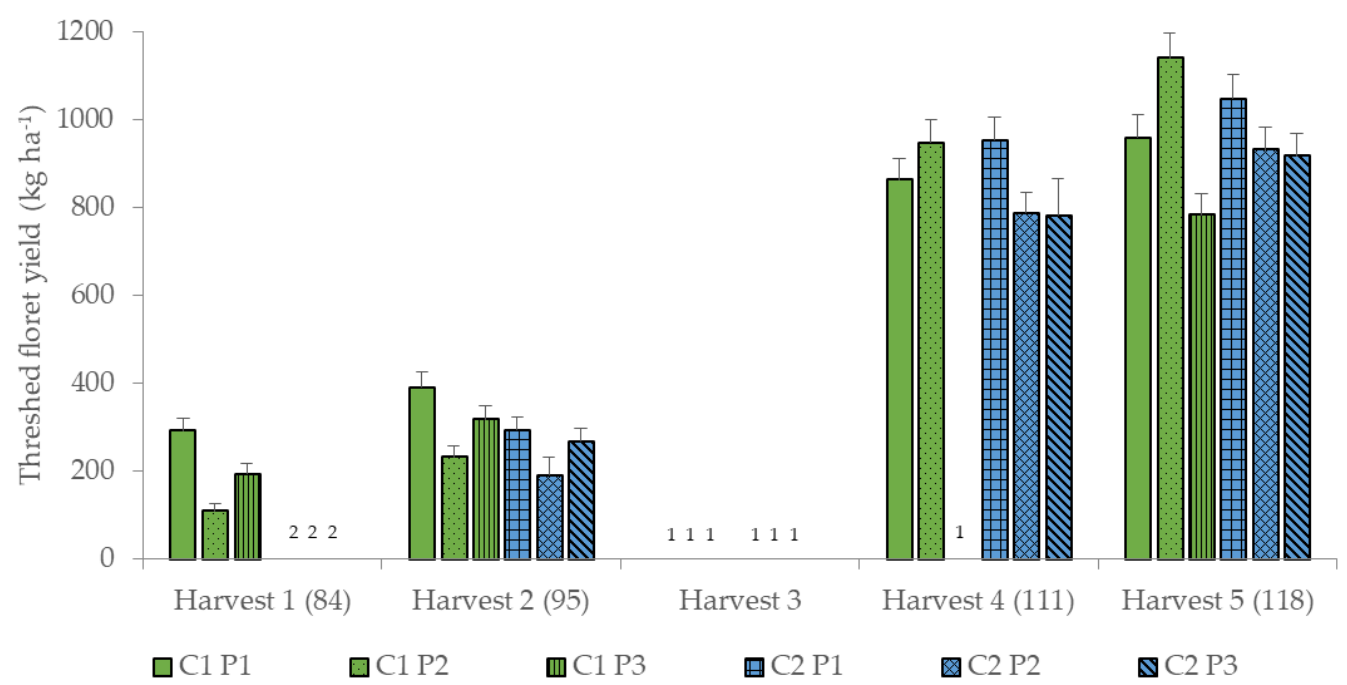

Figure 2. Threshed floret yield $\left(\mathrm{kg} \mathrm{ha}^{-1}\right)$ for the six different treatment combinations of two safflower cultivars (German and Chinese cultivar, $\mathrm{C} 1$ and $\mathrm{C} 2$ ) and three threshing parameter settings (P1-P3) (Table 1) at five harvest dates (Harvest 1-5) (DAS, days after sowing) for the two years (a) 2017 and (b) 2018, represented as mean values \pm standard error. ${ }^{1}$ Harvest was not possible. ${ }^{2}$ Not yet harvested because not yet flowered. ${ }^{3}$ No longer harvested because no longer flowered.

Table 3. ANOVA table of the significant terms and interactions of threshed floret yield.

\begin{tabular}{ccc}
\hline \multicolumn{4}{c}{ ANOVA Table of the Highest Significant Terms and Interactions } \\
\hline Model Term & Degrees of Freedom & $p$-Value ${ }^{\mathbf{1}}$ \\
\hline Year & 1 & 0.0015 \\
\hline Cultivar $^{*}$ Threshing parameter setting & 2 & 0.0284 \\
\hline Harvest date * Threshing parameter setting & 8 & $<0.0001$ \\
\hline$p$-value of an F-test for differences between levels of the corresponding factor or factor combinations.
\end{tabular}


Therefore, marginal means for years and cultivar-by-threshing parameter settings-by-harvest date of threshed floret yields are presented. On average, the threshed floret yield was higher in 2018 (621.58 $\mathrm{kg} \mathrm{ha}^{-1}$ ) than in 2017 (512.14 $\mathrm{kg} \mathrm{ha}^{-1}$ ) (Figure 2 and Table A1). Threshed floret yield increased at later harvest date (Figure 2 and Table A1). C1 achieved the highest threshed floret yield with the threshing parameter setting P2 (1141.76 $\left.\mathrm{kg} \mathrm{ha}^{-1}\right)$, while C2 achieved the maximum yields with the threshing parameter setting P1 (1048.63 $\mathrm{kg} \mathrm{ha}^{-1}$ ) at the fifth harvest (Figure 2 and Table A1). The lowest yields were obtained from both cultivars with P2 at the first or second harvest date $\left(\mathrm{C} 1: 110.46 \mathrm{~kg} \mathrm{ha}^{-1} ; \mathrm{C} 2\right.$ : $192.05 \mathrm{~kg} \mathrm{ha}^{-1}$ ). For C2, threshing parameter setting P1 led to the highest yield at all harvest dates (294.95-1048 $\left.\mathrm{kg} \mathrm{ha}^{-1}\right)$. C1, on the other hand, had the highest yields at the early harvest dates with P1 (Harvest date 1: 293.64; Harvest date 2: $392.67 \mathrm{~kg} \mathrm{ha}^{-1}$ ). For the third to fifth harvest date, the settings of P2 were more favorable (540.51-1141.76 kg ha-1). Threshed floret yield ranged between 110.46 and $1141.76 \mathrm{~kg} \mathrm{ha}^{-1}$ (Figure 2). Other studies in which only the petals were harvested by hand showed that the yields ranged between 2.30 and $647.53 \mathrm{~kg} \mathrm{ha}^{-1}$, depending on cultivar, harvest date and year $[3,28,38-40,42,43,61,62]$. The higher yields in threshing compared to hand harvesting (pure florets) can be explained by the fact that, despite sieving, the threshed material still contained other plant parts, e.g., small leaves or seeds (Figure 2).

Other studies indicated higher floret yields in warmer and drier years [38,63-65]. In this study, higher yields were achieved in 2018, the year with higher temperatures and more importantly less rainfall, which could also be related to lower susceptibility to diseases in drier conditions [51]. Furthermore, floret yields depended on year, harvest date and cultivar [28,31,38-40,42]. The highest threshed floret yields were obtained for both cultivars at the last harvest date in 2018, which could be described by the consecutive flowering of the secondary and tertiary capitula [2,5], and the increasing maturity of the plant which resulted in drier, and thus better threshing conditions. This increasing maturity and drying of the crop (Table 4 ) could also be a reason for the significant interactions of harvest date and threshing parameters.

In contrast to another study, in which marigold was harvested by machine and in which the highest yields were achieved at earlier harvest dates [66], this study did not only focus on the inflorescence. Safflower was harvested with a combine harvester instead of a virtual rotating comb-type chamomile harvester, which is specifically designed for flower harvesting. Therefore, in this study the yields were higher at the end of the harvest dates, when the plant has more biomass and it is more important that the threshed material is drier. C2 achieved the highest threshed floret yields at all harvest dates and $\mathrm{C} 1$ at the first two harvest dates with P1 (Figure 2 and Table A1), which could be explained by the larger openings of the top and bottom sieve (Table 2). Due to these larger sieve diameters, they do not clog quickly by the wet threshing material, therefore there is less threshing loss and a higher threshed floret yield. $\mathrm{C} 1$ has a developmental advantage compared to the other cultivar results in more mature, drier plants and florets at an earlier date. This explains why P2 for drier material properties no longer clogged the smaller sieve diameters. Hence, the highest threshed floret yields could be achieved by low threshing losses (Figure 2 and Table A1). In addition, the higher threshing drum speeds of P1 and P2 compared to P3 potentially led to a higher threshing efficiency and therefore to higher threshed floret yields under these parameter settings. This was also shown in several studies with different crops $[48,54,56]$. The lowest threshed floret yields at the third and fifth harvest date were achieved with P3. The reasons could be the higher wind, the lower threshing drum rpm or the inserted rub bars, which may have led to more material being transported out of the combine harvester as threshing loss. The fact that P3 performed worse than P1 and P2 could also be due to the wider concave setting. That wider concave setting led to a lower threshing efficiency with a higher floret loss. This was also shown in a study by Pragalyaashree et al. [67] where onion florets were separated. 
Table 4. Dry matter content (\%) for the six different treatment combinations of the two cultivars (German and Chinese cultivar, C1 and C2) and three threshing parameter settings (P1-P3) (Table 1) at five harvest dates (Harvest 1-5) (DAS, days after sowing) for the two years (2017 and 2018) represented as mean values \pm standard error.

\begin{tabular}{|c|c|c|c|c|c|c|}
\hline \multirow{2}{*}{ Year } & \multirow{2}{*}{ Treatment } & \multicolumn{5}{|c|}{ Harvest Date } \\
\hline & & 1 & 2 & 3 & 4 & 5 \\
\hline & & & & 100 DAS & 111 DAS & \\
\hline \multirow[t]{7}{*}{2017} & C1 P1 & 1 & 1 & $28.47 \pm 0.70$ & 3 & 3 \\
\hline & C1 P2 & 1 & 1 & $31.23 \pm 0.70$ & 3 & 3 \\
\hline & C1 P3 & 1 & 1 & $32.50 \pm 0.70$ & 3 & 3 \\
\hline & C2 P1 & 1,2 & 1 & $28.47 \pm 0.70$ & $36.77 \pm 0.70$ & 3 \\
\hline & C2 P2 & 1,2 & 1 & $31.20 \pm 0.70$ & $40.13 \pm 0.70$ & 3 \\
\hline & C2 P3 & 1,2 & 1 & $30.73 \pm 0.70$ & $42.23 \pm 0.70$ & 3 \\
\hline & & 84 DAS & 95 DAS & & 111 DAS & 118 DAS \\
\hline \multirow[t]{6}{*}{2018} & C1 P1 & $34.22 \pm 0.90$ & $33.12 \pm 0.89$ & 1 & $51.84 \pm 0.90$ & $65.38 \pm 0.90$ \\
\hline & C1 P2 & $33.39 \pm 0.90$ & $32.16 \pm 0.90$ & 1 & $58.48 \pm 0.89$ & $70.86 \pm 0.90$ \\
\hline & C1 P3 & $29.61 \pm 0.90$ & $32.88 \pm 0.90$ & 1 & 1 & $77.77 \pm 0.91$ \\
\hline & C2 P1 & 2 & $27.82 \pm 0.90$ & 1 & $52.09 \pm 0.91$ & $62.67 \pm 0.91$ \\
\hline & C2 P2 & 2 & $30.11 \pm 1.50$ & 1 & $55.42 \pm 0.90$ & $68.31 \pm 0.91$ \\
\hline & C2 P3 & 2 & $29.71 \pm 0.91$ & 1 & $57.21 \pm 1.50$ & $72.53 \pm 0.91$ \\
\hline \multicolumn{7}{|c|}{ ANOVA table of the significant terms and interactions. } \\
\hline \multicolumn{5}{|c|}{ Model term } & Degrees of freedom & $p$-value ${ }^{4}$ \\
\hline \multicolumn{5}{|c|}{ Year } & 1 & $<0.0001$ \\
\hline \multicolumn{5}{|c|}{ Harvest date* Cultivar* Threshing parameter setting } & 3 & 0.0188 \\
\hline
\end{tabular}

\subsection{Dry Matter Content}

The analysis showed significant differences for year and for the three-way interactions of cultivar, threshing parameter setting and harvest date. Therefore marginal means of the four-way interactions are presented (Table 4 ).

In 2017, the average dry matter content of $33.53 \%$ was less than the average achieved dry matter content in 2018 (48.78\%) (Tables 4 and A1). Further, a higher the dry matter content was achieved at later harvest dates (Tables 4 and A1). Both cultivars C1 and C2 achieved the highest dry matter contents at the last harvest date (C1: 77.77\%; C2: 72.53\%) (Tables 4 and A1). For cultivar C1 the lowest dry matter contents were obtained at the third harvest date in $2017(28.47 \%)$, while C2 reached the lowest dry matter contents at the second harvest date in 2018 (27.82\%) (Tables 4 and A1). In general, comparison of the threshing parameters demonstrated that at the earlier harvest dates (harvest date 1 and 2), with P1 the highest threshed floret yields could be achieved with C1 (Figure 2), which could be explained by the highest dry matter contents ( 34.22 and $33.12 \%$ ) and the resulting better threshability (Table 4). At later harvest dates (harvest date 4 or 5), P3 was the setting with the lowest threshed floret yields (Figure 2). This could be due to the too high dry matter contents (Table 4), which with the higher wind setting of P3 led to higher losses and thus to lower yields (Table 1 and Figure 2). Further, on mostly all harvest dates cultivar $\mathrm{C} 1$ showed higher dry matter contents than $\mathrm{C} 2$ (C1: $28.47-77.77 \%$; $\mathrm{C} 2$ : $27.82-72.53 \%$ ). Comparing this with values of chamomile or marigold flowers [49,68], for example, where the dry matter content at harvest is about $26-30 \%$, the values of this study are higher, i.e., the 
crop is drier, which could also be due to the fact that it is not only the pure product of the flowers. Therefore, the values of dry matter contents can be better compared with late cuts for ensiling or hay purposes, when the whole plant is harvested. In these cases, the dry matter contents at the beginning of flowering were around 16-38\% [69-72]. These values are comparable to the dry matter contents at the first and second harvest date in this study. These studies also showed the increasing dry matter content with increasing maturity (later harvest dates), which was also observed in this study [69-72]. The higher dry matter contents in 2018 could be due to the weather, which was warmer and drier. Higher temperatures lead to an earlier maturity of the crop [73,74], which could explain the earlier increased dry matter contents in 2018. The higher dry matter contents of $\mathrm{C} 1$ could be explained by the developmental advantage of about one week compared to C2. The highest threshed floret yields at the last harvest date (Figure 2 and Table A1) could be explained by the high dry matter contents. Higher dry matter contents (lower moisture contents) increase the threshing efficiency [48,54-56], and thus the threshed floret yield.

\subsection{Carthamidin Content}

As the analysis showed significant differences between years and for the three-way interactions of cultivars, threshing parameter setting and harvest date, medians of the four-way interactions are presented in Table 5.

Table 5. Carthamidin content (\%) for the six different treatment combinations of the two cultivars (German and Chinese cultivar, C1 and C2) and three threshing parameter settings (P1-P3) (Table 1) at five harvest dates (Harvest 1-5) (DAS, days after sowing) for the two years (2017 and 2018) represented as median values \pm standard error.

\begin{tabular}{|c|c|c|c|c|c|c|}
\hline \multirow{2}{*}{ Year } & \multirow{2}{*}{ Treatment } & \multicolumn{5}{|c|}{ Harvest Date } \\
\hline & & 1 & 2 & 3 & 4 & 5 \\
\hline & & & & 100 DAS & 111 DAS & \\
\hline \multirow[t]{7}{*}{2017} & C1 P1 & 1 & 1 & $0.30 \pm 0.03$ & 3 & 3 \\
\hline & $\mathrm{C} 1 \mathrm{P} 2$ & 1 & 1 & $0.23 \pm 0.02$ & 3 & 3 \\
\hline & C1 P3 & 1 & 1 & $0.41 \pm 0.04$ & 3 & 3 \\
\hline & C2 P1 & 1,2 & 1 & $0.48 \pm 0.04$ & $0.31 \pm 0.03$ & 3 \\
\hline & C2 P2 & 1,2 & 1 & $0.44 \pm 0.04$ & $0.27 \pm 0.02$ & 3 \\
\hline & C2 P3 & 1,2 & 1 & $0.96 \pm 0.09$ & $0.35 \pm 0.03$ & 3 \\
\hline & & 84 DAS & 95 DAS & & 111 DAS & 118 DAS \\
\hline \multirow[t]{6}{*}{2018} & C1 P1 & $0.87 \pm 0.05$ & $0.53 \pm 0.03$ & 1 & $0.59 \pm 0.04$ & $0.49 \pm 0.03$ \\
\hline & $\mathrm{C} 1 \mathrm{P} 2$ & $0.80 \pm 0.05$ & $0.54 \pm 0.03$ & 1 & $0.54 \pm 0.03$ & $0.43 \pm 0.03$ \\
\hline & C1 P3 & $1.40 \pm 0.09$ & $0.90 \pm 0.05$ & 1 & 1 & $0.62 \pm 0.04$ \\
\hline & C2 P1 & 2 & $2.42 \pm 0.15$ & 1 & $1.80 \pm 0.11$ & $1.33 \pm 0.08$ \\
\hline & C2 P2 & 2 & $1.90 \pm 0.18$ & 1 & $1.74 \pm 0.11$ & $1.50 \pm 0.09$ \\
\hline & C2 P3 & 2 & $3.14 \pm 0.19$ & 1 & $2.37 \pm 0.22$ & $2.05 \pm 0.13$ \\
\hline \multicolumn{7}{|c|}{ ANOVA table of the significant terms and interactions. } \\
\hline \multicolumn{5}{|c|}{ Model term } & Degrees of freedom & $p$-value ${ }^{4}$ \\
\hline \multicolumn{5}{|c|}{ Year } & 1 & $<0.0001$ \\
\hline \multicolumn{5}{|c|}{ Harvest date* Cultivar* Threshing parameter setting } & 3 & 0.0016 \\
\hline
\end{tabular}

${ }^{1}$ Harvest was not possible. ${ }^{2}$ Not yet harvested because not yet flowered. ${ }^{3}$ No longer harvested because no longer flowered. ${ }^{4}$ The $p$-value of an F-test for differences between levels of the corresponding factor or factor combinations. 
In 2018, higher carthamidin contents could be achieved (on average 1.30\%), than in $2017(0.42 \%)$ (Tables 5 and A1). Both cultivars reached the highest carthamidin content in 2018 with threshing parameter setting $\mathrm{P} 3, \mathrm{C} 1$ with $1.4 \%$ at the first harvest date, $\mathrm{C} 2$ with $3.14 \%$ at the second harvest date (Tables 5 and A1). In contrast, both cultivars achieved the lowest carthamidin contents in 2017 with P2, $\mathrm{C} 1$ at the third harvest date with $0.23 \%, \mathrm{C} 2$ at the fourth harvest date with $0.27 \%$. In general, it was shown that for both cultivars P3 achieved the highest carthamidin contents $(0.35-3.14 \%)$, while P2 showed the lowest contents at most harvest dates (0.23-1.90\%) (Tables 5 and A1). The carthamidin contents ranged between 0.23 and $3.14 \%$ (Table 5). The other parts in the threshing material, such as small leaves or seeds, could explain the lower carthamidin content in comparison to the pure florets, which ranged between 2.68 and $8.12 \%$ and depended on cultivars, harvest dates and years [38,39]. Different cultivars, harvest dates and their interaction could have an influence on the carthamidin content, which was also shown in this study $[5,38-40,75,76]$. In this study, the highest carthamidin contents were achieved at the first two harvest dates, which can be explained by the oxidative and enzymatic degradation of the yellow carthamidin to the red carthamin caused by ripening [77-79]. This was also shown in several studies where the highest carthamidin contents were achieved at earlier harvest dates [38,39]. Steberl et al. [38] also showed that year 2018 with its dry conditions had a positive influence on the carthamidin content. Reasons for this could be that safflower is adapted to warm and arid weather conditions and has a low disease incidence under these conditions [51,63-65]. This could lead to good plant development during flowering, especially in 2018 when temperatures were higher and thus to high carthamidin contents. The higher carthamidin content of $C 2$ in contrast to $C 1$ was shown in a study by Steberl et al. [38].

In general, the lowest carthamidin contents were achieved with P2, which could be due to the fact that this setting has the smallest sieve diameters. Therefore, sieves most likely became clogged and the small florets could not be collected. In contrast, the highest carthamidin levels were achieved with P3 for both cultivars and all harvest dates. This could be related to the wider opening of the concave and the rub bars used. They help to ensure that the florets are better rubbed off from the capitula, whereby a higher proportion of florets can be obtained and due to the generally lower threshed floret yield (Figure 2), the ratio of florets to residual material can be increased and thus explain the higher carthamidin contents. In a study by Ehlert and Beier in which a chamomile harvester was tested, it was found that at higher ground speed the lower rotation speed led to a higher proportion of capitula in the harvested goodcrop compared to higher rotation speeds [80]. This may explain why P3 with a lower threshing drum speed may have a higher proportion of capitula and thus a higher carthamidin content.

\subsection{Carthamidin Yield}

For the carthamidin yield, the analysis showed significant differences for year and various two-way interactions of threshing parameter setting, harvest date and cultivar (Table 6).

Table 6. ANOVA table of the significant terms and interactions of carthamidin yield.

\begin{tabular}{ccc}
\hline \multicolumn{3}{c}{ ANOVA Table of the Highest Significant Terms and Interactions } \\
\hline Model Term & Degrees of Freedom & $p$-Value ${ }^{\mathbf{1}}$ \\
\hline Year & 1 & $<0.0001$ \\
\hline Cultivar * $^{*}$ Threshing parameter setting & 2 & 0.0350 \\
\hline Harvest date * Threshing parameter setting & 8 & $<0.0001$ \\
\hline
\end{tabular}

Therefore, medians of the corresponding four-way interactions are presented (Figure 3). 
(a)

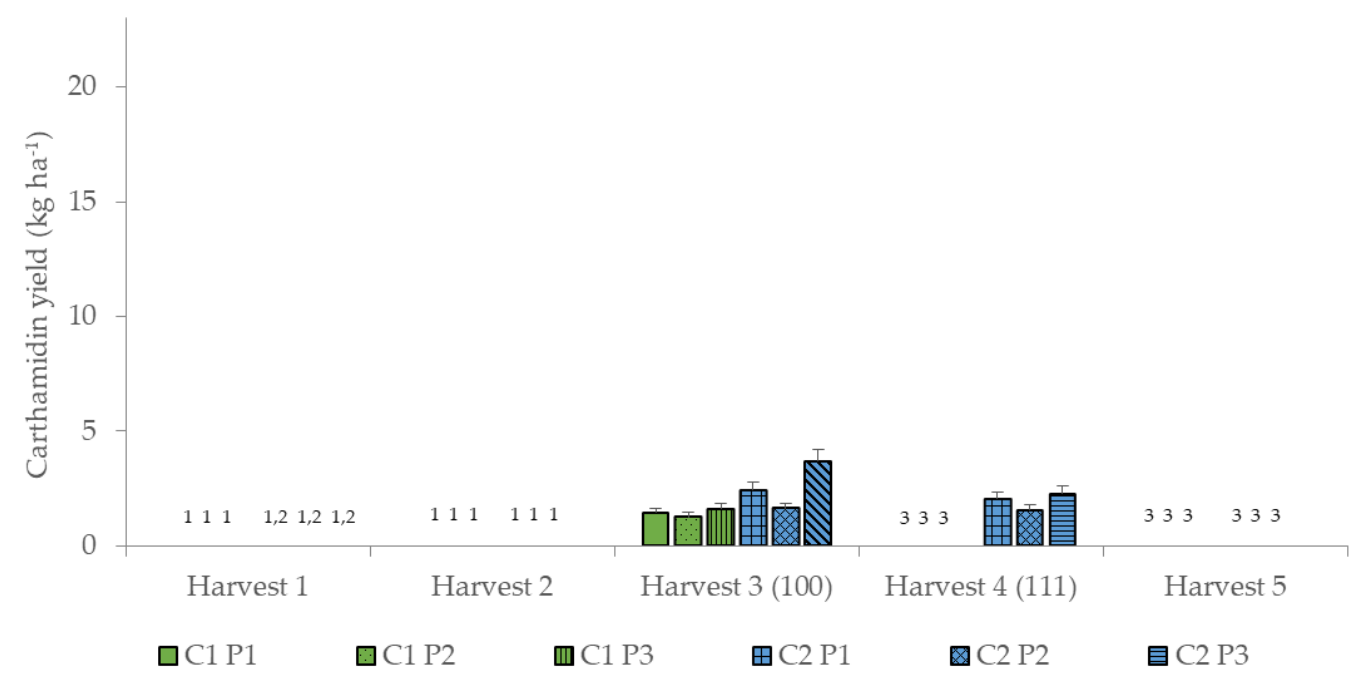

(b)

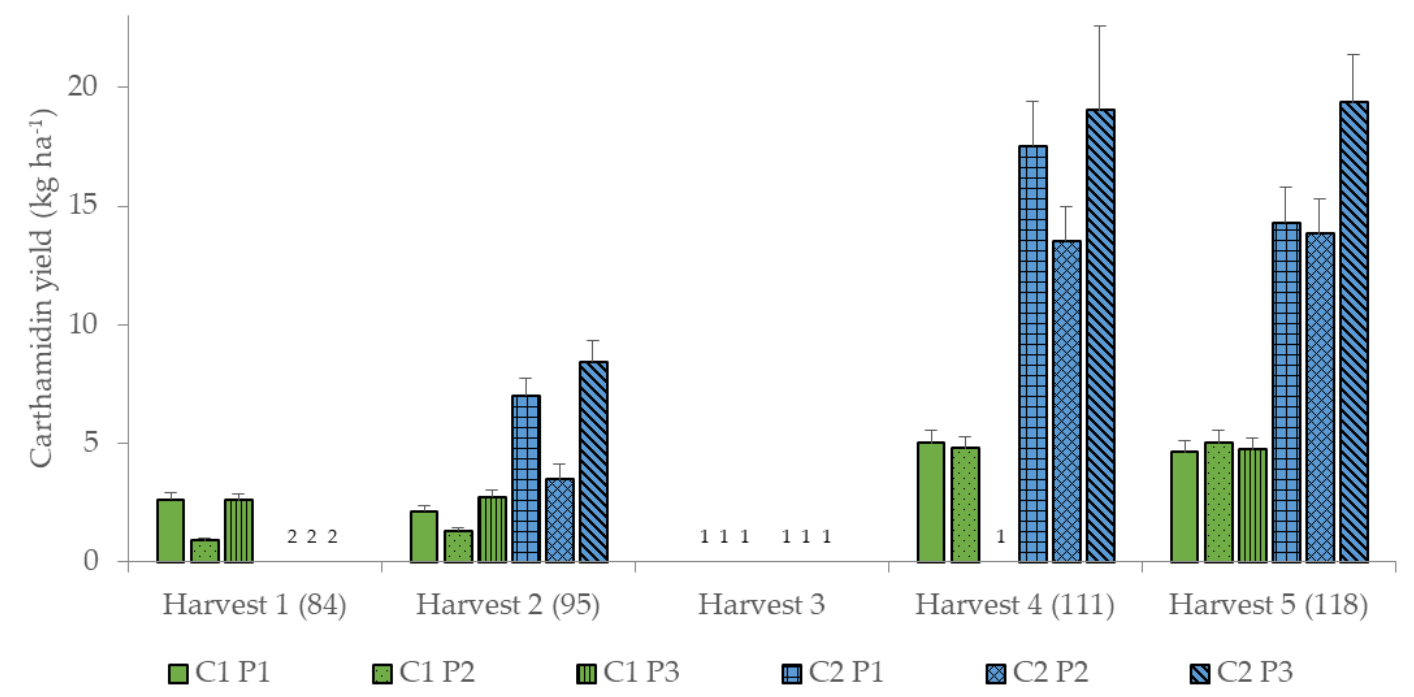

Figure 3. Carthamidin yield $\left(\mathrm{kg} \mathrm{ha}^{-1}\right)$ for the six different treatment combinations of two cultivars (German and Chinese cultivar, C1 and C2) and three threshing parameter settings (P1-P3) (Table 1) at the five harvest dates (Harvest 1-5) (DAS, days after sowing) for the two years (a) 2017 and (b) 2018, represented as median values \pm standard error. ${ }^{1}$ Harvest was not possible. ${ }^{2}$ Not yet harvested because not yet flowered. ${ }^{3}$ No longer harvested because no longer flowered.

In 2017, an average carthamidin yield of $2.0 \mathrm{~kg} \mathrm{ha}^{-1}$ was achieved, while in 2018 higher carthamidin yields were observed with around $7.7 \mathrm{~kg} \mathrm{ha}^{-1}$ (Figure 3 and Table A1). Generally, C2 had higher carthamidin yields than C1, and P2 resulted in lower carthamidin yields compared to P1 and P3 (Figure 3 and Table A1). C1 produced the highest carthamidin yield with P2 at the fifth harvest (5.03 $\mathrm{kg} \mathrm{ha}^{-1}$ ), while at the previous harvest dates with P2 the lowest carthamidin yields were recorded (Figure 3 and Table A1). The highest carthamidin yields of C2 were reached at all harvest dates with P3 (2.27-19.36 kg ha-1), whereas the least amount of yields were obtained with P2 (1.55-13.83 kg ha $\left.{ }^{-1}\right)$. The carthamidin yields ranged from 0.91 to $19.36 \mathrm{~kg} \mathrm{ha}^{-1}$ (Figure 3). In comparison to other studies, where the carthamidin yields were between 0.04 and $37.86 \mathrm{~kg} \mathrm{ha}^{-1}$ depending on cultivar, harvest date and year [38,39], the carthamidin yields of the threshing samples are in the middle range, which can be 
explained by the addition of other plant parts such as leaves and seeds and the lower carthamidin contents (Table 5). The highest carthamidin yields were obtained by C2 with P3 at the fifth harvest in 2018, which was mainly due to the high threshed floret yields at that date (Figure 2), and the still relatively high carthamidin contents of around $2 \%$ (Table 5). The drier and hotter weather conditions in 2018 led to a better ripening of the plants (Table 4), resulting in better threshing. Therefore, in 2018 high carthamidin contents were achieved with P3, resulting in the highest carthamidin yields.

\subsection{Relationship between Individual Head Weight and Carthamidin Content}

The results presented above (Sections 3.1-3.4) showed with which combine harvester parameter settings, on which harvest dates the highest yields, the highest carthamidin contents and thus also the highest carthamidin yields could be achieved. The results indicated significant differences between the two cultivars $\mathrm{C} 1$ and $\mathrm{C} 2$, especially in the carthamidin contents, which then led to higher carthamidin yields of the $\mathrm{C} 2$ cultivar (Table 5 and Figure 3). The data analysis revealed cultivar traits, which are important for both mechanical harvesting and carthamidin yield. As in general the threshing performance and efficiency depends, among other factors, on the crop and on the ear (spike) shape and size [47,81-83], the capitula size/weight of the tested cultivars was examined in more detail. As a study by Mozaffari and Asadi revealed that the capitulum diameter and the capitulum weight correlated significantly with each other [84], the current study considered the weight of the capitula only.

The individual capitula weights of the two cultivars $\mathrm{C} 1$ and $\mathrm{C} 2$ revealed that the weight of the capitula decreased at later harvest dates (Figure 4).

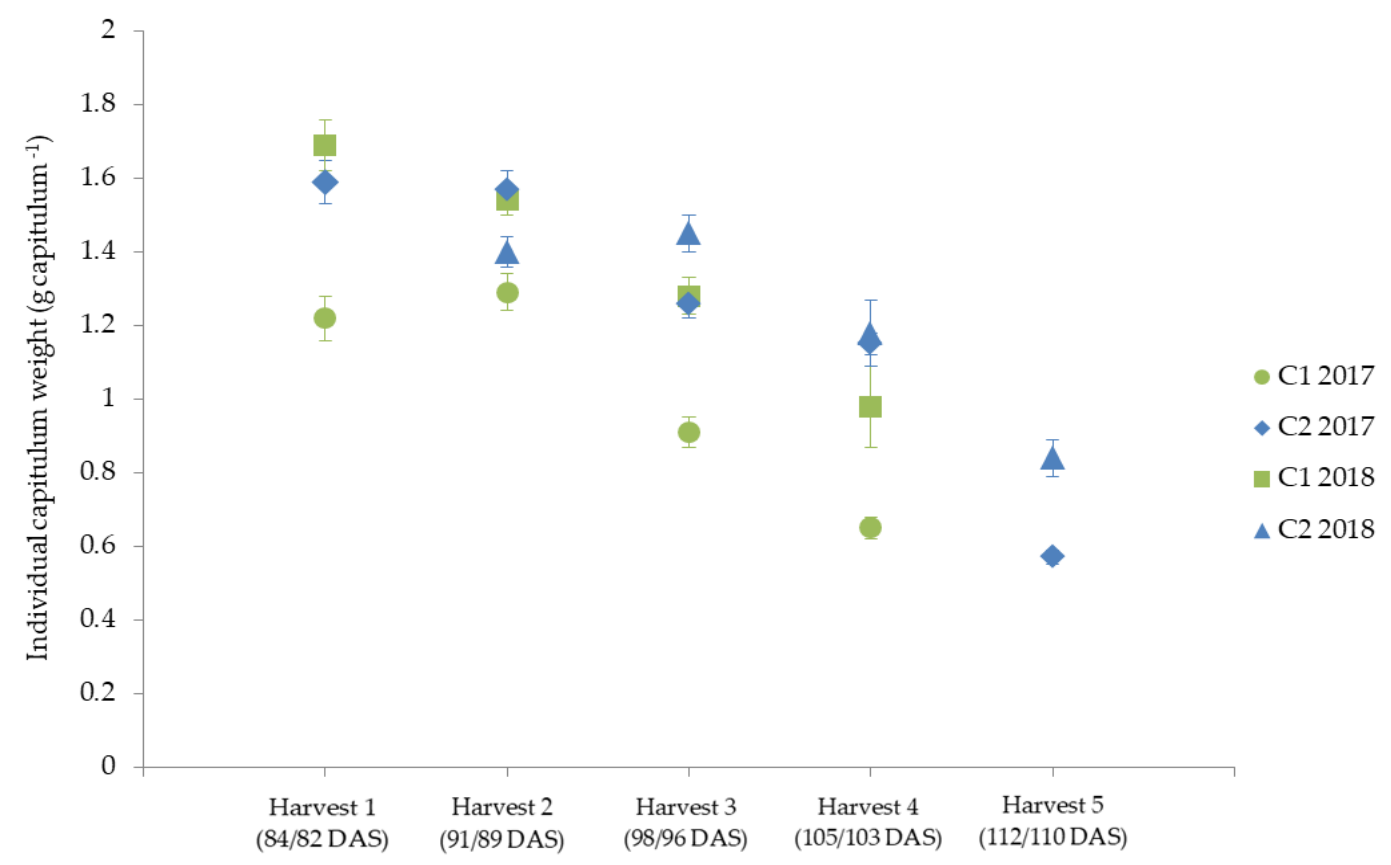

Figure 4. Individual capitulum weight $\left(\mathrm{g} \mathrm{capitulum}^{-1}\right)$ for the two cultivars ( $\mathrm{C} 1$ and $\left.\mathrm{C} 2\right)$ for the five harvest dates (Harvest 1-5) in 2017 and 2018, represented as mean values \pm standard error.

C2 had a higher average individual capitula weight than C1 (Figure 4). One possible reason for the decrease in individual capitula weight could be that the primary capitula are formed first; the secondary and tertiary order capitula, which are less productive, are formed at a later stage [85]. This is in line with other studies about marigold and chamomile, which showed that flowers harvested at an earlier harvest date tend to be larger and thus have more weight $[66,86]$. Reasons for the cultivar differences could be the genetically influenced weight of the capitula $[87,88]$, or, for example, the origin of the cultivar, which also has an influence on the size of the capitula [89]. The study by Knowles [89] showed that cultivars from the Middle East and Egypt had the largest capitula size, while cultivars 
from Europe had average capitula size. This could explain the larger capitula size and weight of C2, which originates from China.

Since both the threshed floret yield and the carthamidin content are decisive for the carthamidin yield, the carthamidin content for the selection of cultivars was also examined more closely. For this parameter, a decrease with increasing harvest date and a cultivar difference was shown. This was already illustrated and discussed in the study of Steberl et al. [38]. Reasons for the decreasing carthamidin content at later harvest dates can be explained by the oxidative degradation of the colorant, which changes from yellow to red and therefore the yellow dye (carthamidin) decreases [77-79]. In a study by Salem et al., it was shown that in safflower the flavonoid content, to which the yellow dye of safflower belongs, both decreased with increasing developmental status and depended on the flower color [90]. It was shown that the flavonoid content is higher in orange flowers [90], which are mainly found in C2, than in yellow flowers (C1) [38]. This can also explain the higher carthamidin content of $\mathrm{C} 2$

Since the two factors, individual capitula weight and carthamidin content, depend both on cultivar and harvest date and decreased at later harvest date, both parameters (capitula weight and carthamidin content) are presented against each other (Figure 5).

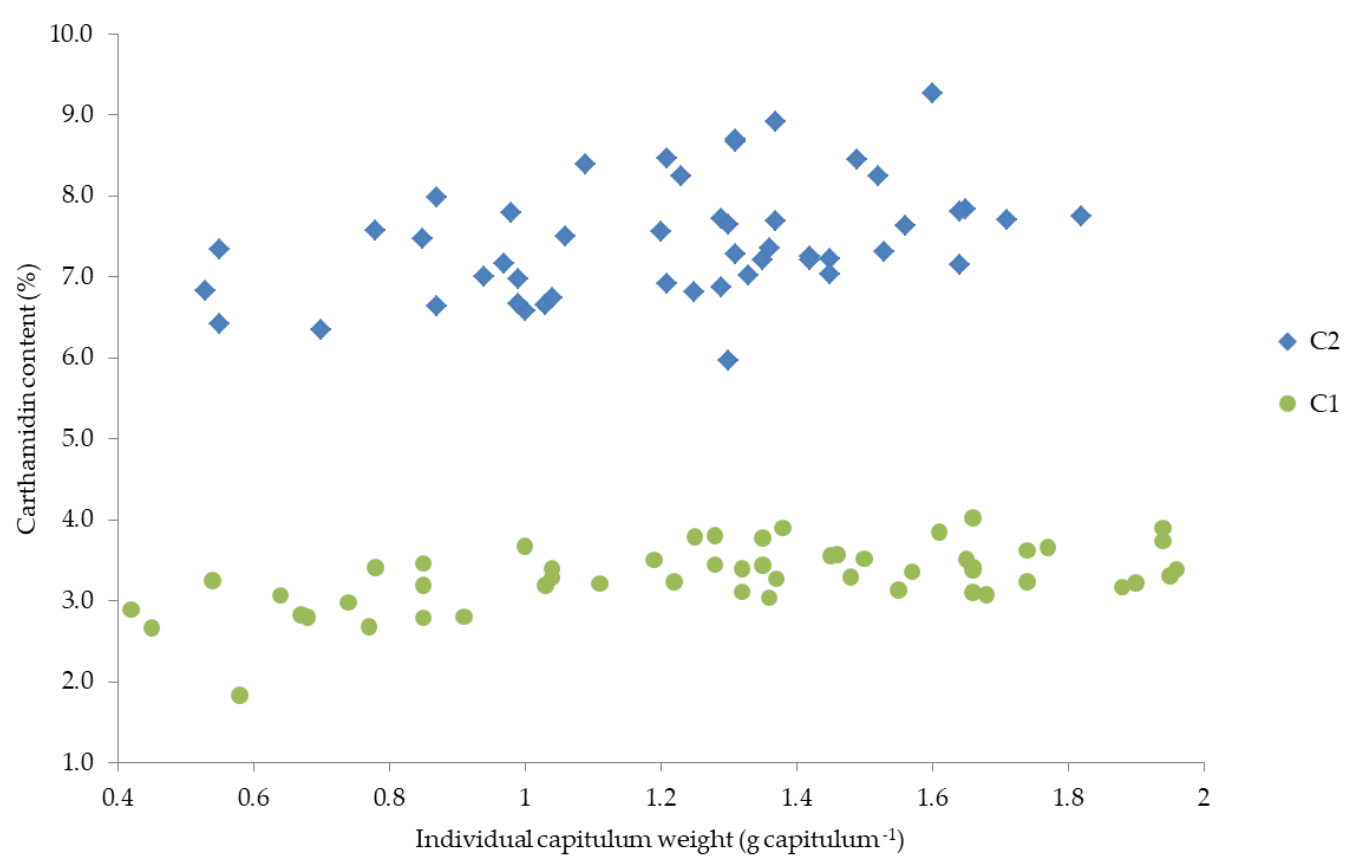

Figure 5. Relationship between individual capitulum weight and carthamidin content of the two cultivars (C1 and C2).

Figure 5 indicates a relationship between carthamidin content and individual capitula weight. However, it could not be statistically revealed whether this relationship is based only on the fact that both characteristics decreased with later harvest date or whether it is based on a correlation between the two characteristics capitula weight and carthamidin content. The dependence of the flavonoid content on the weight of the fruit and on the size of the flower/fruit has been shown in several studies [91,92]. In cranberries, an increase in anthocyanins was observed with increasing fruit weight [91], while in lemon an increasing concentration of two flavonoids was observed with increasing fruit size [92]. This is in line with the results of this study, in which the carthamidin content increased with increasing individual capitulum weight. In a study of Mohammadi and Tavakoli [39] similar results were observed, indicating that the cultivar with the smallest capitula size produced the lowest carthamidin content, while the highest carthamidin contents were obtained from medium and large capitula. This could explain the higher carthamidin contents of C2. In addition, in a study 
with spelt wheat narrower ears resulted in a lower threshability [93], which could explain the better threshability of the larger capitula of $\mathrm{C} 2$ and thus the higher carthamidin content. Further, higher yields and carthamidin contents of $\mathrm{C} 2$ could be explained by the correlation of capitula size/weight and the floret yield [31]. Therefore, many studies argue in favor of a possible correlation between capitula weight and carthamidin content independent of the harvest date. Further investigations should therefore be made with both small and large capitulas and their carthamidin content should be examined separately to confirm this hypothesis.

\section{Conclusions}

This study tested the potential mechanization of floret harvest in safflower and revealed the impact on overall floret yield and carthamidin content. In general, to achieve highest carthamidin yields the Chinese cultivar (C2) with the threshing parameter setting P3 at the fourth or fifth harvest date (111-118 DAS (days after sowing)) can be recommended for harvesting safflower florets with a combine harvester.

As the carthamidin yields are in the middle range of those of hand harvesting, further trials should be carried out with further threshing parameter settings and with components of the combine harvester especially developed for this crop and the intended utilization of florets in the food coloring industry. Further improvements could then possibly eliminate the post-harvest sieving process. In addition, since threshability was influenced by the size/shape of the ear/capitula, which mainly depends on the cultivar, and capitula weight and carthamidin content are apparently related to each other, the capitula weight could be used as a criterion for selecting suitable safflower cultivars. The focus could be on cultivars with larger capitula, which should be further selected by breeding. When selecting cultivars, care should also be taken to assure duration to reach maturity, and thus higher dry matter contents, as higher threshed floret yields and carthamidin yields were obtained with higher dry matter contents.

Overall, threshing of florets with a combine harvester seems to be feasible. This offers the chance to reduce the high cost of manual harvests in the future, thus enabling an economic production of florets for the food coloring industry in southwestern Germany.

Author Contributions: Conceptualization, K.S. and S.G.-H.; methodology, K.S. and S.G.-H.; software, K.S. and J.H.; formal analysis, K.S.; investigation, K.S.; resources, K.S. and S.G.-H.; data curation, K.S.; writing-original draft preparation, K.S.; writing-review and editing, K.S., J.H. and S.G.-H.; visualization, K.S.; supervision, S.G.-H.; project administration, S.G.-H.; funding acquisition, S.G.-H. All authors have read and agreed to the published version of the manuscript.

Funding: This research was funded by the German Federal Ministry for Economic Affairs and Energy within the Central Innovation Program for SMEs, grant number 16KN050530.

Acknowledgments: The authors would like to thank the technical staff of the Experimental Station Ihinger Hof of the University of Hohenheim for the agronomic management of the field trials, manpower and the possibility to use the devices. Many thanks to the men from Zürn Harvesting GmbH \& Co. KG for their man power and the provision of their plot combine harvester. The authors would also like to thank Andrea Richter for her help during the field trials.

Conflicts of Interest: The authors declare no conflict of interest. The funders had no role in the design of the study; in the collection, analyses, or interpretation of data; in the writing of the manuscript, or in the decision to publish the results. 


\section{Appendix A}

Table A1. Simple means for the interactions of factors year (2017 and 2018), harvest date (Harvest $1-5)$, threshing parameter setting (P1-P3) and cultivars (C1 and C2). A letter display was added to allow for pairwise comparisons $(\alpha=0.05)$. Harvest date-by-year means with at least one identical lowercase letter are not significantly different from each other for each cultivar and threshing parameter setting combination. Threshing parameter setting-by-year means with at least one identical capital letter are not significantly different from each other for each cultivar and harvest date combination. Cultivar-by-year means with at least one identical Greek letter are not significantly different from each other for each harvest date and threshing parameter setting combination.

\begin{tabular}{|c|c|c|c|c|c|}
\hline Parameter & Year & $\begin{array}{c}\text { Harvest } \\
\text { Date }\end{array}$ & $\begin{array}{c}\text { Threshing } \\
\text { Parameter Setting }\end{array}$ & Cultivar C1 & Cultivar C2 \\
\hline \multirow{18}{*}{$\begin{array}{l}\text { Threshed floret } \\
\text { yield }\left(\mathrm{kg} \mathrm{ha}^{-1}\right)\end{array}$} & \multirow{6}{*}{2017} & \multirow{3}{*}{3} & 1 & $484.21^{\mathrm{aA} \alpha} \pm 67.51$ & $517.71^{\mathrm{aA} \alpha} \pm 69.80$ \\
\hline & & & 2 & $540.51^{\mathrm{aA} \alpha} \pm 71.32$ & $372.70^{\mathrm{bA} \alpha} \pm 59.23$ \\
\hline & & & 3 & $400.91^{\mathrm{aA} \alpha} \pm 61.43$ & $384.08^{\mathrm{bA} \alpha} \pm 60.12$ \\
\hline & & \multirow{3}{*}{4} & 1 & n.d. & $660.91^{\mathrm{aA} \alpha} \pm 78.87$ \\
\hline & & & 2 & n.d. & $576.42^{\mathrm{aA} \alpha} \pm 73.65$ \\
\hline & & & 3 & n.d. & $671.82^{\mathrm{aA} \alpha} \pm 79.51$ \\
\hline & \multirow{12}{*}{2018} & \multirow{3}{*}{1} & 1 & $293.64^{\mathrm{cA} \alpha} \pm 28.67$ & n.d. \\
\hline & & & 2 & $110.46^{\mathrm{dC} \alpha} \pm 17.58$ & n.d. \\
\hline & & & 3 & $194.61^{\mathrm{cB} \alpha} \pm 23.34$ & n.d. \\
\hline & & \multirow{3}{*}{2} & 1 & $392.67^{\mathrm{bA} \alpha} \pm 33.15$ & $294.95^{\mathrm{bA} \beta} \pm 28.73$ \\
\hline & & & 2 & $233.66^{\mathrm{cB} \alpha} \pm 25.57$ & $192.05^{\mathrm{cA} \alpha} \pm 40.89$ \\
\hline & & & 3 & $319.66^{\mathrm{bA} \alpha} \pm 29.91$ & $269.67^{\mathrm{bA} \alpha} \pm 27.47$ \\
\hline & & \multirow{3}{*}{4} & 1 & $864.74^{\mathrm{aA} \alpha} \pm 49.20$ & $954.45^{\mathrm{aA} \alpha} \pm 51.69$ \\
\hline & & & 2 & $949.77^{\mathrm{bA} \alpha} \pm 51.56$ & $788.98^{\mathrm{bB} \beta} \pm 46.99$ \\
\hline & & & 3 & n.d. & $783.15^{\mathrm{aAB} \alpha} \pm 82.58$ \\
\hline & & \multirow{3}{*}{5} & 1 & $961.24^{\mathrm{aB} \alpha} \pm 51.87$ & $1048.63^{\mathrm{aA} \alpha} \pm 54.18$ \\
\hline & & & 2 & $1141.76^{\mathrm{aA} \alpha} \pm 56.53$ & $933.83^{\mathrm{aA} \beta} \pm 51.13$ \\
\hline & & & 3 & $784.78^{\mathrm{aC} \alpha} \pm 46.87$ & $918.91^{\mathrm{aA} \alpha} \pm 50.72$ \\
\hline \multirow{18}{*}{ Dry matter content (\%) } & \multirow{6}{*}{2017} & \multirow{3}{*}{3} & 1 & $28.47^{\mathrm{aB} \alpha} \pm 0.70$ & $28.47^{\mathrm{bB} \alpha} \pm 0.70$ \\
\hline & & & 2 & $31.23^{\mathrm{aA} \alpha} \pm 0.70$ & $31.20^{\mathrm{bA} \alpha} \pm 0.70$ \\
\hline & & & 3 & $32.50^{\mathrm{aA} \alpha} \pm 0.70$ & $30.73^{\mathrm{bA} \alpha} \pm 0.70$ \\
\hline & & \multirow{3}{*}{4} & 1 & n.d. & $36.77^{\mathrm{aB} \alpha} \pm 0.70$ \\
\hline & & & 2 & n.d. & $40.13^{\mathrm{aA} \alpha} \pm 0.70$ \\
\hline & & & 3 & n.d. & $42.23^{\mathrm{aA} \alpha} \pm 0.70$ \\
\hline & \multirow{12}{*}{2018} & \multirow{3}{*}{1} & 1 & $34.22^{\mathrm{cA} \alpha} \pm 0.90$ & n.d. \\
\hline & & & 2 & $33.39^{\mathrm{cA} \alpha} \pm 0.90$ & n.d. \\
\hline & & & 3 & $29.61^{\mathrm{cB} \alpha} \pm 0.90$ & n.d. \\
\hline & & \multirow{3}{*}{2} & 1 & $33.12^{\mathrm{cA} \alpha} \pm 0.89$ & $27.82^{\mathrm{cA} \beta} \pm 0.90$ \\
\hline & & & 2 & $32.16^{\mathrm{cA} \alpha} \pm 0.90$ & $30.11^{\mathrm{cA} \alpha} \pm 1.50$ \\
\hline & & & 3 & $32.88^{\mathrm{bA} \alpha} \pm 0.90$ & $29.71^{\mathrm{cA} \beta} \pm 0.91$ \\
\hline & & \multirow{3}{*}{4} & 1 & $51.84^{\mathrm{bB} \alpha} \pm 0.90$ & $52.09^{\mathrm{bB} \alpha} \pm 0.91$ \\
\hline & & & 2 & $58.48^{\mathrm{bA} \alpha} \pm 0.89$ & $55.42^{\mathrm{bA} \beta} \pm 0.90$ \\
\hline & & & 3 & 3 & $57.21^{\mathrm{bA} \alpha} \pm 1.50$ \\
\hline & & \multirow{3}{*}{5} & 1 & $65.38^{\mathrm{aC} \alpha} \pm 0.90$ & $62.67^{\mathrm{aC} \beta} \pm 0.91$ \\
\hline & & & 2 & $70.86^{\mathrm{aB} \alpha} \pm 0.90$ & $68.31^{\mathrm{aB} \alpha} \pm 0.91$ \\
\hline & & & 3 & $77.77^{\mathrm{aA} \alpha} \pm 0.91$ & $72.53^{\mathrm{aA} \beta} \pm 0.91$ \\
\hline
\end{tabular}


Table A1. Cont.

\begin{tabular}{|c|c|c|c|c|c|}
\hline Parameter & Year & $\begin{array}{l}\text { Harvest } \\
\text { Date }\end{array}$ & $\begin{array}{c}\text { Threshing } \\
\text { Parameter Setting }\end{array}$ & Cultivar C1 & Cultivar C2 \\
\hline \multirow{18}{*}{$\begin{array}{l}\text { Carthamidin content } \\
(\%)\end{array}$} & \multirow{6}{*}{2017} & \multirow{3}{*}{3} & 1 & $0.30^{\mathrm{aB} \beta} \pm 0.03$ & $0.48^{\mathrm{aB} \alpha} \pm 0.04$ \\
\hline & & & 2 & $0.23^{\mathrm{aB} \beta} \pm 0.02$ & $0.44^{\mathrm{aB} \alpha} \pm 0.04$ \\
\hline & & & 3 & $0.41^{\mathrm{aA} \beta} \pm 0.04$ & $0.96^{\mathrm{aA} \alpha} \pm 0.09$ \\
\hline & & \multirow{3}{*}{4} & 1 & n.d. & $0.31^{\mathrm{bA} \alpha} \pm 0.03$ \\
\hline & & & 2 & n.d. & $0.27^{\mathrm{bA} \alpha} \pm 0.02$ \\
\hline & & & 3 & n.d. & $0.35^{\mathrm{bA} \alpha} \pm 0.03$ \\
\hline & \multirow{12}{*}{2018} & \multirow{3}{*}{1} & 1 & $0.87^{\mathrm{aB} \alpha} \pm 0.05$ & n.d. \\
\hline & & & 2 & $0.80^{\mathrm{aB} \alpha} \pm 0.05$ & n.d. \\
\hline & & & 3 & $1.40^{\mathrm{aA} \alpha} \pm 0.09$ & n.d. \\
\hline & & \multirow{3}{*}{2} & 1 & $0.53^{\mathrm{bcB} \beta} \pm 0.03$ & $2.42^{\mathrm{aB} \alpha} \pm 0.15$ \\
\hline & & & 2 & $0.54^{\mathrm{bB} \beta} \pm 0.03$ & $1.90^{\mathrm{aC} \alpha} \pm 0.18$ \\
\hline & & & 3 & $0.90^{\mathrm{bA} \beta} \pm 0.05$ & $3.14^{\mathrm{aA} \alpha} \pm 0.19$ \\
\hline & & \multirow{3}{*}{4} & 1 & $0.59^{\mathrm{bA} \beta} \pm 0.04$ & $1.80^{\mathrm{bB} \alpha} \pm 0.11$ \\
\hline & & & 2 & $0.54^{\mathrm{bA} \beta} \pm 0.03$ & $1.74^{\mathrm{abB} \alpha} \pm 0.11$ \\
\hline & & & 3 & n.d. & $2.37^{\mathrm{bA} \alpha} \pm 0.22$ \\
\hline & & \multirow{3}{*}{5} & 1 & $0.49^{\mathrm{cB} \beta} \pm 0.03$ & $1.33^{\mathrm{cC} \alpha} \pm 0.08$ \\
\hline & & & 2 & $0.43^{\mathrm{cB} \beta} \pm 0.03$ & $1.50^{\mathrm{bB} \alpha} \pm 0.09$ \\
\hline & & & 3 & $0.62^{\mathrm{cA} \beta} \pm 0.04$ & $2.05^{\mathrm{bA} \alpha} \pm 0.13$ \\
\hline \multirow{18}{*}{$\begin{array}{l}\text { Carthamidin yield } \\
\quad\left(\mathrm{kg} \mathrm{ha}^{-1}\right)\end{array}$} & \multirow{6}{*}{2017} & \multirow{3}{*}{3} & 1 & $1.45^{\mathrm{aA} \beta} \pm 0.20$ & $2.43^{\mathrm{aAB} \alpha} \pm 0.34$ \\
\hline & & & 2 & $1.26^{\mathrm{aA} \alpha} \pm 0.18$ & $1.64^{\mathrm{aB} \alpha} \pm 0.23$ \\
\hline & & & 3 & $1.62^{\mathrm{aA} \beta} \pm 0.23$ & $3.68^{\mathrm{aA} \alpha} \pm 0.52$ \\
\hline & & \multirow{3}{*}{4} & 1 & n.d. & $2.05^{\mathrm{aA} \alpha} \pm 0.28$ \\
\hline & & & 2 & n.d. & $1.55^{\mathrm{aA} \alpha} \pm 0.22$ \\
\hline & & & 3 & n.d. & $2.27^{\mathrm{bA} \alpha} \pm 0.32$ \\
\hline & \multirow{12}{*}{2018} & \multirow{3}{*}{1} & 1 & $2.65^{\mathrm{bA} \alpha} \pm 0.28$ & n.d. \\
\hline & & & 2 & $0.91^{\mathrm{cB} \alpha} \pm 0.10$ & n.d. \\
\hline & & & 3 & $2.62^{\mathrm{bA} \alpha} \pm 0.27$ & n.d. \\
\hline & & \multirow{3}{*}{2} & 1 & $2.16^{\mathrm{bA} \beta} \pm 0.23$ & $7.01^{\mathrm{bA} \alpha} \pm 0.74$ \\
\hline & & & 2 & $1.32^{\mathrm{bB} \beta} \pm 0.14$ & $3.49^{\mathrm{bB} \alpha} \pm 0.65$ \\
\hline & & & 3 & $2.75^{\mathrm{bA} \beta} \pm 0.29$ & $8.44^{\mathrm{bA} \alpha} \pm 0.88$ \\
\hline & & \multirow{3}{*}{4} & 1 & $5.01^{\mathrm{aA} \beta} \pm 0.53$ & $17.55^{\mathrm{aA} \alpha} \pm 1.84$ \\
\hline & & & 2 & $4.80^{\mathrm{aA} \beta} \pm 0.50$ & $13.54^{\mathrm{aA} \alpha} \pm 1.42$ \\
\hline & & & 3 & n.d. & $19.05^{\mathrm{aA} \alpha} \pm 3.53$ \\
\hline & & \multirow{3}{*}{5} & 1 & $4.65^{\mathrm{aA} \beta} \pm 0.49$ & $14.30^{\mathrm{aB} \alpha} \pm 1.50$ \\
\hline & & & 2 & $5.03^{\mathrm{aA} \beta} \pm 0.53$ & $13.83^{\mathrm{aB} \alpha} \pm 1.45$ \\
\hline & & & 3 & $4.74^{\mathrm{aA} \beta} \pm 0.50$ & $19.36^{\mathrm{aA} \alpha} \pm 2.03$ \\
\hline
\end{tabular}

\section{References}

1. Emongor, V. Safflower (Carthamus tinctorius L.) the underutilized and neglected crop: A review. Asian J. Plant Sci. 2010, 9, 299-306. [CrossRef]

2. Dajue, L.; Mündel, H.H. Safflower Carthamus Tinctorius L.; IPGRI, IPK, Eds.; IPGRI: Rome, Italy, 1996; ISBN 9290432977.

3. Weiss, E.A. Oilseed Crops, 2nd ed.; Blackwell Science: Oxford, UK, 2000; ISBN 0632052597. 
4. Mokhtassi-Bidgoli, A.; Akbari, G.A.; Mirhadi, M.J.; Pazoki, A.R.; Soufizadeh, S. Yield components, leaf pigment contents, patterns of seed filling, dry matter, LAI and LAID of some safflower (Carthamus tinctorius L.) genotypes in Iran. Pak. J. Biol. Sci. 2007, 10, 1406-1413. [CrossRef] [PubMed]

5. Emongor, V.; Oagile, O. Safflower Production; Impression House Publication: Gaborone, Botswana, 2017; ISBN 978-99968-0-607-0.

6. Corleto, A.; Alba, E.; Polignano, G.B.; Vonghio, G. Safflower: A multipurpose species with unexploited potential and world adaptability. The research in Italy. In Safflower: A Multipurpose Species with Unexploited Potential and World Adaptability, Proceedings of the Fourth International Safflower Conference, Bari, Italy, 2-7 June, 1997; Corleto, A., Mündel, H.-H., Eds.; Adruatica Editrice: Bari, Italy, 1997; pp. 23-31.

7. Ekin, Z. Resurgence of safflower (Carthamus tinctorius L.) utilization: A global view. J. Agron. 2005, 4, 83-87.

8. Velasco, L.; Fernández-Martínez, J.M. Progress in breeding for modified tocopherol content and composition in safflower. In Sesame and Safflower Newsletter; Institute of Sustainable Agriculture, Ed.; Institute of Sustainable Agriculture: Cordoba, Spain, 2002; pp. 98-102.

9. Weiss, E.A. Castor, Sesame and Safflower; Hill: London, UK, 1971; ISBN 0249440210.

10. Garfield, S. Mauve. How One Man Invented a Color that Changed the World; W.W. Norton \& Company: New York, NY, USA, 2002; ISBN 9780393323139.

11. Arnold, L.E.; Lofthouse, N.; Hurt, E. Artificial food colors and attention-deficit/hyperactivity symptoms: Conclusions to dye for. Neurotherapeutics 2012, 9, 599-609. [CrossRef] [PubMed]

12. Bateman, B.; Warner, J.O.; Hutchinson, E.; Dean, T.; Rowlandson, P.; Gant, C.; Grundy, J.; Fitzgerald, C.; Stevenson, J. The effects of a double blind, placebo controlled, artificial food colourings and benzoate preservative challenge on hyperactivity in a general population sample of preschool children. Arch. Dis. Child. 2004, 89, 506-511. [CrossRef]

13. Kř́žová, H. Natural dyes: Their past, present, future and sustainability. Recent Dev. Fibrous Mater. Sci. 2015, $12,59-71$.

14. Kumar, J.K.; Sinha, A.K. Resurgence of natural colourants: A holistic view. Nat. Prod. Res. 2004, 18, 59-84. [CrossRef]

15. Yusuf, M.; Shabbir, M.; Mohammad, F. Natural colorants: Historical, processing and sustainable prospects. Nat. Prod. Bioprospect. 2017, 7, 123-145. [CrossRef]

16. Grand View Research, Inc. Natural Food Colors Market Estimates \& Trend Analysis by Product (Curcumin, Carotenoids, Anthocyanin, Carmine, Chlorophyllin), by Application (Bakery \& Confectionery, Beverages, Dairy \& Frozen Products, Meat Products), and Segment Forecasts, 2018-2025. Available online: https: //www.grandviewresearch.com/industry-analysis/natural-food-colors-market (accessed on 6 May 2020).

17. Future Market Insights. Natural Food Colours Market: Significant Demand for Clean Label and Naturally Sourced Ingredients in Food Products Spurring Revenue Growth: Global Industry Analysis (2013-2017) \& Opportunity Assessment (2018-2028). Available online: https://www.futuremarketinsights.com/reports/ global-natural-food-colours-market (accessed on 6 May 2020).

18. European Comission. Guidance Notes on the Classification if Food Extracts with Colouring Properties. Available online: https://ec.europa.eu/food/safety/food_improvement_agents/additives/eu_ rules_en (accessed on 6 May 2020).

19. Bratinova, S. Provision of Scientific and Technical Support with Respect to the Classification of Extracts/Concentrates with Colouring Properties either as Food Colours (Food Additives Falling under Regulation (EC) No 1333/2008) or Colouring Foods; Publications Office of the European Union: Luxembourg, 2015; ISBN 978-92-79-50607-9.

20. GNT International B.V. Europäische Union Verabschiedet Guidance Notes zur Klassifizierung Färbender Lebensmittel, 2013. Available online: https://www.food-monitor.de/2013/12/europaeische-unionverabschiedet-giudance-notes-zur-klassifizierung-faerbender-lebensmittel/ (accessed on 8 May 2020).

21. Rudolf Wild GmbH \& Co. KG. EU-Leitlinien: Die Übergangsfrist für färbende Lebensmittel Endet, 2015. Available online: https://www.lvt-web.de/topstories/fooddesign-hygiene-und-ueberwachung/eu-leitliniendie-uebergangsfrist-fuer-faerbende-lebe (accessed on 8 May 2020).

22. Dajue, L. Progress research and production in China. In Proceedings of the Third International Safflower Conference, Beijing, China, 14-18 June 1993; Dajue, L., Yuanzhou, H., Eds.; Beijing Botanical Garden, Institute of Botany, Chinese Academy of Sciences: Beijing, China, 1993; pp. 35-46.

23. Shin, Y.-S.; Yoo, D.-I. Storage stability and color reproducibility of yellow and red dyes extracted from Carthamus tinctorius L. Text. Coloration Finish. 2012, 24, 165-172. [CrossRef] 
24. Yoon, J.-M.; Cho, M.-H.; Park, J.-E.; Kim, Y.-H.; Hahn, T.-R.; Paik, Y.-S. Thermal stability of the pigments hydroxysafflor yellow A, safflor yellow B, and precarthamin from safflower (Carthamus tinctorius). J. Food Sci. 2003, 68, 839-843. [CrossRef]

25. Food and Agriculture Organization of the United Nations. FAOSTAT-Crop statistics: Safflower. Available online: http://www.fao.org/faostat/en/\#data/QC (accessed on 7 May 2020).

26. Gao, W.Y.; Fan, L.; Paek, K.Y. Yellow and red pigment production by cell cultures of Carthamus tinctorius in a bioreactor. Plant Cell Tissue Organ Cult. 2000, 60, 95-100. [CrossRef]

27. Singh, V.; Nimbkar, N. Safflower (Carthamus tinctorius L.), Chapter 6. In Genetic Resources, Chromosome Engineering, and Crop Improvement; Singh, R.J., Ed.; CRC Press: Boca Raton, FL, USA, 2007; pp. 167-194. ISBN 9780849336393.

28. Nagaraj, G. Oilseeds. Properties, Processing, Products and Procedures; New India Public Agency: Pitam Pura, New Delhi, India, 2009; ISBN 9788190723756.

29. Fatahi, N.; Carapetian, J.; Heidari, R. Spectrophotometric measurement of valuable pigments from petals of safflower (Carthamus tinctorius L.) and their identification by TLC method. Res. J. Biol. Sci. 2008, 3, 761-763.

30. Srinivas, C.V.S.; Praveena, B.; Nagaraj, G. Safflower petals: A source of gamma linolenic acid. Plant Foods Hum. Nutr. 1999, 54, 89-92. [CrossRef] [PubMed]

31. Singh, V.; Kolekar, N.M.; Nimbkar, N. Breeding strategy for improvement of flowers and seed yields in safflower. In Safflower: Unexploited Potential and World Adaptability, Proceedings of the Seventh International Safflower Conference, Wagga Wagga, New South Wales, Australia, 3-6 November 2008; Knights, S.E., Potter, T.D., Eds.; Agri-MC Marketing and Communication: Bendigo, Australia, 2008; ISBN 978-0-646-50329-5.

32. Yu, H.; Xu, L.X. Separation and determination of flavonols in the flowers of Carthamus tinctorius by RP-HPLC. Acta Pharm. Sin. 1997, 32, 120-122.

33. Elfadl, E.; Reinbrecht, C.; Claupein, W. Evaluation of phenotypic variation in a worldwide germplasm collection of safflower (Carthamus tinctorius L.) grown under organic farming conditions in Germany. Genet. Resour. Crop. Evol. 2010, 57, 155-170. [CrossRef]

34. Elfadl, E.; Reinbrecht, C.; Claupein, W. Safflower (Carthamus tinctorius L.) as a new oil crop in organic farming system: Potential and stability in central Europe. Int. J. AgriScience 2012, 2, 477-495.

35. Elfadl, E.Y.; Reinbrecht, C.; Frick, C.; von Witzke, S.; Rudolphi, S.; Claupein, W.; Esendal, E.; Bergman, J.W.; Kandemir, N.; Johnson, R.C.; et al. Genotype by environment interaction in safflower (Carthamus tinctorius L.) grown under organic farming system in Central Europe. In Safflower: A Unique Crop for Oil Spices and Health Consequently, a Better Life for You, Proceedings of the Sixth International Safflower Conference, Istanbul, Turkey, 6-10 June 2005; Esendal, E., Bergman, J.W., Eds.; Engin Maatbacılık Ltd. Şti: Istanbul, Turkey, 2005; pp. $39-43$.

36. Frick, C.; Hebeisen, T.; Reinbrecht, C. Safflower Oil Production in Switzerland, 2005. Available online: https://www.agrarforschungschweiz.ch/en/2005/04/safflower-oil-production-in-switzerland/ (accessed on 8 May 2020).

37. Reinbrecht, C.; Barth, S.; von Witzke-Ehbrecht, S.; Frick, C.; Elfadl, E.; Kahnt, G.; Becker, H.C.; Claupein, W.; Esendal, E.; Bergman, J.W.; et al. Screening of a worldwide safflower collection for adaptation to humid temperate climates and cultivation in organic farming. In Safflower: A Unique Crop for Oil Spices and Health Consequently, a Better Life for You, Proceedings of the Sixth International Safflower Conference, Istanbul, Turkey, 6-10 June 2005; Esendal, E., Bergman, J.W., Eds.; Engin Maatbacılık Ltd. Şti: Istanbul, Turkey, 2005; pp. $236-242$.

38. Steberl, K.; Hartung, J.; Munz, S.; Graeff-Hönninger, S. Effect of Row Spacing, Sowing Density, and Harvest Time on Floret Yield and Yield Components of Two Safflower Cultivars Grown in Southwestern Germany. Agronomy 2020, 10, 664. [CrossRef]

39. Mohammadi, M.; Tavakoli, A. Effect of harvest time of spring safflower (Carthamus tinctorius L.) florets on the production of red and yellow pigments. Qual. Assur. Saf. Crop. Foods 2015, 7, 581-588. [CrossRef]

40. Kizil, S.; Çakmak, Ö.; Kirici, S.; İnan, M. A Comprehensive Study on Safflower (Carthamus tinctorius L.) in Semi-Arid Conditions. Biotechnol. Biotechnol. Equip. 2008, 22, 947-953. [CrossRef]

41. Azari, A.; Khajehpour, M.R. Effect of planting pattern on development, growth, yield components and seed and petal yields of safflower in summer planting, local variety of Isfahan, Koseh. Person. J. Sci. Technol. Agric. Nat. Resour. 2005, 9, 131-142.

42. Hamza, M. Influence of different plant densities on crop yield of six safflower genotypes under Egyptian newly reclaimed soils conditions. Int. J. Agric. Crop. Sci. 2015, 8, 168-173. 
43. Jianguo, Y. Carthamin Yellow, $\mathrm{As}, \mathrm{Pb}$ and $\mathrm{Hg}$ contents in different safflower cultivars. In Proceedings of the Second International Safflower Conference, Hyderabad, India, 9-13 January 1989; Ranga Rao, V., Ramachandram, M., Eds.; Indian Society of Oilseeds Research: Hyderabad, India, 1989; pp. 367-371.

44. Azimi, S.; Chegini, G.; Kianmehr, M.H. Design and manufacture of safflower petal harvester machine. Mech. Ind. 2012, 13, 301-305. [CrossRef]

45. Yun, G.; Lixin, Z.; Ying, Q.; Xiaopan, J.; Yuanbo, C. Dynamic model for sucking process of pneumatic cutting-type safflower harvest device. Int. J. Agric. Biol. Eng. 2016, 9, 43-50. [CrossRef]

46. McGuire, P.E.; Damania, A.B.; Qualset, C.O. Safflower in California. The Paulden F. Knowles personal history of plant exploration and research on evolution, genetics, and breeding. In Agronomy Progress Report No. 313; University of California: Davis, CA, USA; pp. 1-44.

47. Kailashkumar, E.B. Study of Different Kinds of Threshers \& Factors Influencing threshing of Crops: A Revies. Int. J. Sci. Res. Dev. 2019, 6, 65-73.

48. Naveen Kumar, D.B.; Kumar, P.; Arun Kumar, H.S.; Sandeep, T.N.; Sudjadevi, G. Efficiency of mechanical thresher over traditional method of threshing finger millet. Int. J. Agric. Eng. 2013, 6, 184-188.

49. Zimmer, S.; Müller, J. Literatursammlung und -auswertung zur Erntetechnologie von Arznei- und Gewürzpflanzen: Schlussbericht zum Vorhaben. Laufzeit, 1 December 2002. [CrossRef]

50. Flemmer, A.C.; Franchini, M.C.; Lindström, L.I. Description of safflower (Carthamus tinctorius) phenological growth stages according to the extended BBCH scale. Ann. Appl. Biol. 2015, 166, 331-339. [CrossRef]

51. Mündel, H.H.; Blackshaw, R.E.; Byers, J.R.; Huang, H.C.; Johnson, D.L.; Keon, R.; Kubik, J.; McKenzie, R.; Otto, B.; Roth, B.; et al. Safflower Production on the Canadian Prairies: Revisited in 2004; Graphcom Printers Ltd.: Lethbridge, AB, Canada, 2004; ISBN 0662382099.

52. Anderson, R.L. Broadleaf weed control in safflower (Carthamus tinctorius) with sulfonylurea herbicides. Weed Technol. 1987, 1, 242-246. [CrossRef]

53. Blackshaw, R.E.; Mündel, H.-H.; Derksen, D.A. Herbicides for weed control in safflower (Carthamus tinctorius). Can. J. Plant Sci. 1990, 70, 237-245. [CrossRef]

54. Gbabo, A.; Gana, I.M.; Amoto, M.S. Design, fabrication and testing of a millet thresher. Net J. Agric. Sci. 2013, $1,100-106$.

55. Goel, A.K.; Behera, D.; Swain, S.; Behera, B.K. Performance of a low-cost manual sunflower thresher. Indian J. Agric. Res. 2009, 43, 37-41.

56. Adekanye, T.A.; Osakpamwan, A.B.; Osaivbie, I.E. Evaluation of a soybean threshing machine for small scale farmers. Agric. Eng. Int. CIGR e-J. 2016, 18, 426-434.

57. Röhricht, C.; Karte, T.; Schubert, M. Blütendrogen. In Analyse der ökologischen Produktionsverfahren von Heil- und Gewürzpflanzen in Deutschland; Geschäftsstelle Bundesprogramm Ökologischer Landbau in der Bundesanstalt für Landwirtschaft und Ernährung, Ed.; Sächsische Landesanstalt für Landwirtschaft: Leipzig, Germany, 2003; pp. 126-130.

58. Food and Agriculture Organization of the United Nations. Carthamus yellow. In Compendium of Food Additive Specifications, Addendum 6, 52, Add. 6; Food and Nutrition Paper; FAO: Rome, Italy, 1998.

59. Piepho, H.P.; Buchse, A.; Emrich, K. A Hitchhiker's Guide to Mixed Models for Randomized Experiments. J. Agron. Crop. Sci. 2003, 189, 310-322. [CrossRef]

60. Piepho, H.-P. A SAS macro for generating letter displays of pairwise mean comparisons. Commun. Biometry Crop Sci. 2012, 7, 4-13.

61. Knowles, P.F. Safflower-Production, processing and utilization. Econ. Bot. 1955, 9, 273-299. [CrossRef]

62. Omidi, A.H.; Sharifmogadas, M.R. Evaluation of Iranian safflower cultivars reaction to different sowing dates and plant densities. World Appl. Sci. J. 2010, 8, 953-958.

63. Knowles, P.F. The plant geneticist' contribution toward changing lipid and amino acid composition of safflower. J. Am. Oil Chem. Soc. 1972, 49, 27-29. [CrossRef]

64. Armah-Agyeman, G.; Loiland, J.; Karow, R.; Hang, A.N. Safflower. In Dryland Cropping Systems, EM 8792; Oregon State University, Extension Service: Corvallis, OR, USA, 2002; pp. 1-7.

65. Koutroubas, S.D.; Papakosta, D.K.; Doitsinis, A. Phenotypic variation in physiological determinants of yield in spring sown safflower under Mediterranean conditions. Field Crop. Res. 2009, 112, 199-204. [CrossRef]

66. Veselinov, B.; Adamovic, D.; Martinov, M.; Viskovic, M.; Golub, M.; Bojic, S. Mechanized harvesting and primary processing of Calendula officinalis L. inflorescences. Span. J. Agric. Res. 2014, 12, 329. [CrossRef] 
67. Munusamy, P.; Ravi, P.; Ramasamy, K.; Kennedy, J. Effect of feed rate, concave clearance and peripheral speed on the performance evaluation of pre thresher for onion umbels (Allium cepa var Aggregatum L.). Agric. Eng. 2015, 3, 13-22.

68. Hecht, H.; Mohr, T.; Lembrecht, S. Mechanizing the harvest of flower medicinal plants. Landtechnik 1992, 47, 276-280.

69. Corleto, A.; Cazzato, E.; Laudadio, V.; Petrera, F. Evolution of Biomass and Quality of Safflower During the Reproductive Stage for Hay and Ensiling Purposes. In Safflower: A Unique Crop for Oil Spices and Health Consequently, a Better Life for You, Proceedings of the Sixth International Safflower Conference, Istanbul, Turkey, 6-10 June 2005; Esendal, E., Bergman, J.W., Eds.; Engin Maatbacılık Ltd. Şti: Istanbul, Turkey, 2005; pp. 69-73.

70. Peiretti, P.G. Nutritional aspects and potential uses of safflower (Carthamus tinctorius L.) in livestock. In Agricultural Research Updates. Volume 19; Gorawala, P., Mandhatri, S., Eds.; Nova Science Publishers, Inc.: Hauuppauge, NY, USA, 2017; pp. 3-22. ISBN 9781536110128.

71. Peiretti, P.G. Effects of growth stage on chemical composition, organic matter digestibility, gross energy and fatty acid content of safflower (Carthamus tinctorius L.). Livest. Res. Rural Dev. 2009, 21, 206.

72. Cazzato, E.; Laudadio, V.; Corleto, A.; Tufarelli, V. Effects of harvest date, wilting and inoculation on yield and forage quality of ensiling safflower (Carthamus tinctorius L.) biomass. J. Sci. Food Agric. 2011, 91, 2298-2302. [CrossRef] [PubMed]

73. Hatfield, J.L.; Prueger, J.H. Temperature extremes: Effect on plant growth and development. Weather Clim. Extrem. 2015, 10, 4-10. [CrossRef]

74. Wang, J.; Wang, E.; Luo, Q.; Kirby, M. Modelling the sensitivity of wheat growth and water balance to climate change in Southeast Australia. Clim. Chang. 2009, 96, 79-96. [CrossRef]

75. Tabrizi, A.H.O. Floret removal effects on grain and oil yield and their components in spring safflower. In Sesame and Safflower Newsletter; Instituto de Agricultura Sostenible: Cordoba, Spain, 2002; pp. 71-75.

76. Omidi, A.H.; Sharifmoghaddasi, M. Study of safflower varieties for flower and grain yields and fatty acids composition. Adv. Environ. Biol. 2010, 4, 524-527.

77. Ghorbani, E.; Keleshteri, R.H.; Shahbazi, M.; Moradi, F.; Sadri, M. Optimization of extraction yield of carthamine and safflower yellow pigments from safflower (Carthamus tinctorious L.) under different treatments and solvent systems. Res. J. Pharmacogn. 2015, 2, 17-23.

78. Cho, M.H.; Paik, Y.S.; Hahn, T.R. Enzymatic conversion of precarthamin to carthamin by a purified enzyme from the yellow petals of safflower. J. Agric. Food Chem. 2000, 48, 3917-3921. [CrossRef]

79. Saito, K. A new enzymatic method for the extraction of preearthamine from dyer's saffron florets. Z Lebensmitel Unters. Forsch. 1993, 197, 34-36. [CrossRef]

80. Ehlert, D.; Beier, K. Development of picking devices for chamomile harvesters. J. Appl. Res. Med. Aromat. Plants 2014, 1, 73-80. [CrossRef]

81. Oni, K.C.; Ali, M.A. Factors influencing threshability of maize in Nigeria. Agric. Mech. Asia Afr. Lat. Am. 1986, 17, 39-44.

82. Lupton, F.G.H. Wheat Breeding; Springer: Dordrecht, The Netherlands, 1987; ISBN 9789400931312.

83. Sharma, J.S.; Running, K.L.D.; Xu, S.S.; Zhang, Q.; Peters Haugrud, A.R.; Sharma, S.; McClean, P.E.; Faris, J.D. Genetic analysis of threshability and other spike traits in the evolution of cultivated emmer to fully domesticated durum wheat. Mol. Genet. Genom. 2019, 294, 757-771. [CrossRef] [PubMed]

84. Mozaffari, K.; Asadi, A.A. Relationships Among Traits Using Correlation, Principal Components and Path Analysis in Safflower Mutants Sown in Irrigated and Drought Stress Condition. Asian J. Plant Sci. 2006, 5, 977-983.

85. Ramachandram, M.; Ranga Rao, V. Some Considerations For Restructing Traditional Plant Type In Safflower. In Proceedings of the Second International Safflower Conference, Hyderabad, India, 9-13 January 1989; Ranga Rao, V., Ramachandram, M., Eds.; Indian Society of Oilseeds Research: Hyderabad, India, 1989; pp. 133-144.

86. Beier, K.; Ehlert, D. Methods for evaluation of picking performance of chamomile (Matricaria recutita L.) harvesters. Part II: Development of new methods. J. Appl. Res. Med. Aromat. Plants 2014, 1, 35-42. [CrossRef]

87. Arslan, B. Assessing of heritability and variance components of yield and some agronomic traits in different safflower (Carthamus tinctorius L.) cultivars. Asian J. Plant Sci. 2007, 6, 554-557.

88. Camaş, N.; Esendal, E. Estimates of broad-sense heritability for seed yield and yield components of safflower (Carthamus tinctorius L.). Hereditas 2006, 143, 55-57. [CrossRef] 
89. Knowles, P.F. Centers of plant diversity and conservation of crop germ plasm: Safflower. Econ. Bot. 1969, 23, 324-329. [CrossRef]

90. Salem, N.; Msaada, K.; Hamdaoui, G.; Limam, F.; Marzouk, B. Variation in phenolic composition and antioxidant activity during flower development of safflower (Carthamus tinctorius L.). J. Agric. Food Chem. 2011, 59, 4455-4463. [CrossRef]

91. Vvedenskaya, I.O.; Vorsa, N. Flavonoid composition over fruit development and maturation in American cranberry, Vaccinium macrocarpon Ait. Plant Sci. 2004, 167, 1043-1054. [CrossRef]

92. Vandercook, C.E.; Tisserat, B. Flavonoid changes in developing lemons grown in vivo and in vitro. Phytochemistry 1989, 28, 799-803. [CrossRef]

93. Worland, A.J.; Gale, M.D.; Law, C.N. Wheat genetics. In Wheat Breeding: Its Scientific Basis; Lupton, F., Ed.; Springer: Dordrecht, The Netherlands, 2014; ISBN 9789400931312.

(C) 2020 by the authors. Licensee MDPI, Basel, Switzerland. This article is an open access article distributed under the terms and conditions of the Creative Commons Attribution (CC BY) license (http://creativecommons.org/licenses/by/4.0/). 